\title{
Modeling biogeochemical processes in sediments from the Rhône River prodelta area (NW Mediterranean Sea)
}

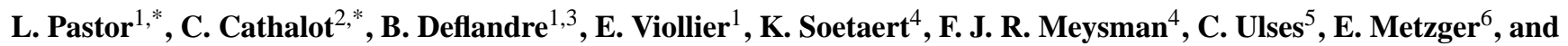 \\ C. Rabouille ${ }^{2}$ \\ ${ }^{1}$ Univ. Paris Diderot, Sorbonne Paris Cité, Institut de Physique du Globe de Paris, UMR7154 CNRS, 75013 Paris, France \\ ${ }^{2}$ Lab. des Sciences du Climat et de l'Environ., CEA-CNRS UMR 1572, Av. de la Terrasse, 91198 Gif sur Yvette, France \\ ${ }^{3}$ UMR5805 EPOC - OASU, Université Bordeaux 1 - CNRS, Avenue des Facultés, 33405 Talence cedex, France \\ ${ }^{4}$ NIOO-KNAW, Centre for Estuarine and Marine Ecology, Korringaweg 7, 4401 NT Yerseke, The Netherlands \\ ${ }^{5}$ Laboratoire d'Aérologie, CNRS et Université de Toulouse, 14 avenue Edouard Belin, 31400 Toulouse, France \\ ${ }^{6}$ Laboratoire des Bio-Indicateurs Actuels et Fossiles, UPRES EA 2644, UFR Sciences 2 bd Lavoisier, \\ 49045 Angers Cedex 01, France \\ *These authors contributed equally to this work.
}

Received: 7 December 2010 - Published in Biogeosciences Discuss.: 19 January 2011

Revised: 13 April 2011 - Accepted: 14 April 2011 - Published: 27 May 2011

\begin{abstract}
In situ oxygen microprofiles, sediment organic carbon content, and pore-water concentrations of nitrate, ammonium, iron, manganese, and sulfides obtained in sediments from the Rhône River prodelta and its adjacent continental shelf were used to constrain a numerical diagenetic model. Results showed that (1) the organic matter from the Rhône River is composed of a fraction of fresh material associated to high first-order degradation rate constants (11$33 \mathrm{yr}^{-1}$ ); (2) the burial efficiency (burial/input ratio) in the Rhône prodelta (within $3 \mathrm{~km}$ of the river outlet) can be up to $80 \%$, and decreases to $\sim 20 \%$ on the adjacent continental shelf $10-15 \mathrm{~km}$ further offshore; (3) there is a large contribution of anoxic processes to total mineralization in sediments near the river mouth, certainly due to large inputs of fresh organic material combined with high sedimentation rates; (4) diagenetic by-products originally produced during anoxic organic matter mineralization are almost entirely precipitated (>97\%) and buried in the sediment, which leads to (5) a low contribution of the re-oxidation of reduced products to total oxygen consumption. Consequently, total carbon mineralization rates as based on oxygen consumption rates and using Redfield stoichiometry can be largely underestimated in such River-dominated Ocean Margins (RiOMar) environments.
\end{abstract}

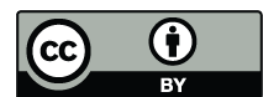

Correspondence to: L. Pastor (lucie.pastor@eas.gatech.edu)

\section{Introduction}

Processes affecting organic matter $(\mathrm{OM})$ in coastal seas sediments are of major importance: OM recycling contributes to the $\mathrm{CO}_{2}$ balance of the coastal ocean (Borges, 2005; Chen and Borges, 2009) and represents a source of new nutrients to the water column (Rizzo and Christian, 1996; Pratihary et al., 2009), thus contributing to the productivity of the coastal zone (Ingall and Jahnke, 1994; Wollast, 1998). It also influences carbon preservation in marine sediments, especially in river deltas (Aller et al., 1996; Berner and Berner, 1996). The suboxic and anoxic oxidation of $\mathrm{OM}$ is of particular interest in these zones since oxygen is consumed rapidly, and thus nitrate, Mn-oxides, Fe-oxides, and sulfate are used as terminal electron acceptors (Canfield et al., 1993a). Numerous secondary reactions such as precipitation/dissolution processes (Mucci and Morse, 1984; Canfield and Berner, 1987; Berelson et al., 1990) and redox reactions (Canfield et al., 1993a, b; Deflandre et al., 2002) take place in the sedimentary column, affecting concentration gradients, and thus diffusive fluxes of dissolved components (Berner, 1980). In particular, it is important to estimate the rates and relative importance of the different mineralization pathways when assessing the modification of organic carbon (OC) fate in response to environmental changes (Holligans and Reiners, 1992). These degradation rates can be determined indirectly from the pore-water concentration profiles coupled to diagenetic models (e.g. Boudreau, 1991, 1997; Rabouille and Gaillard, 1991; Dhakar and Burdige, 1996; Soetaert et al., 1996a;

Published by Copernicus Publications on behalf of the European Geosciences Union. 
Van Cappellen and Wang, 1996; Wang and Van Cappellen, 1996; Berg et al., 2003). These models are based on the 1-D description of the sedimentary column and are mostly applied to environments under steady-state conditions. In this work this approach is utilized to explore a river-dominated ocean margins area (RiOMar) where both benthic mineralization and preservation of organic matter are intense. More particularly, these specific systems which undergo very large sedimentation rates (McKee et al., 2004) still require refinement of our understanding of the interplay between mineralization and burial processes.

The Rhône River prodelta and its adjacent continental shelf is an interesting example of these RiOMar systems. Due to the damming of the Nile, the Rhône River becomes the most important river of the Mediterranean Sea both in terms of water and particle discharges (Copin-Montegut, 1993; Pont et al., 2002). Its influence over the continental shelf of the Gulf of Lions has been widely documented (Monaco et al., 1999; Durrieu de Madron et al., 2000; Sempéré et al., 2000; Lansard et al., 2009). For instance, recent studies highlighted the distribution of organic carbon in the sediments near the Rhone delta and discussed its origin and lability (Tesi et al., 2007; Lansard et al., 2009). Several studies have also emphasized the tight link between the distribution of the Rhône River inputs and the benthic mineralization activity assessed from sediment oxygen fluxes (Lansard et al., 2009; Cathalot et al., 2010; Pastor et al., 2011). Nevertheless, these studies focussed on specific aspects of the benthic OC cycle, while a quantitative approach with a process model including anoxic diagenesis is needed to fully assess the functioning of the Rhône River prodelta and its adjacent continental shelf.

The present study makes use of a diagenetic model constrained by concentration profiles. It provides a better understanding of the biogeochemical cycles in the close vicinity of the Rhône River outlet concerning (1) the fate of particles imported by the Rhône River (mineralization and burial) on a large time scale, (2) the degradability of organic matter (OM) deposited at the sediment surface and its impact on the mineralization processes, (3) the relative importance of anoxic processes vs. oxic processes, and (4) the behaviour of diagenetic products and their contribution in the total oxygen consumption. The latter is important to assess the validity of oxygen microprofiles as a proxy of OC oxidation.

\section{Material and methods}

\subsection{Study area}

The Rhône River is $812 \mathrm{~km}$ long and presents an annual average water discharge of $1700 \mathrm{~m}^{3} \mathrm{~s}^{-1}$ (Pont et al., 2002; Antonelli et al., 2004). Its main channel, Grand Rhône, encompasses $90 \%$ of the total river water flux. The Rhône prodelta represents a $30 \mathrm{~km}^{2}$ area close to the Rhône River mouth (Aloisi et al., 1982; Durrieu de Madron et al., 2000). It is characterized by very high sedimentation rates up to $41 \mathrm{~cm} \mathrm{yr}^{-1}$ and high organic carbon content (1-3\%). Sedimentation rates decrease with distance from the mouth to reach values less than $1 \mathrm{~cm} \mathrm{yr}^{-1}$ on the continental slope (Zuo et al., 1997). The high concentrations of benthic organic carbon in the prodelta reflect the Rhône River inputs, i.e. the amount of organic carbon discharge originating from erosion and runoff in the drainage basin (Buscail et al., 1995; Lansard et al., 2005; Pastor et al., 2011). In its adjacent continental shelf (up to $25 \mathrm{~km}$ from the river outlet), this influence is less marked and some marine influence is observed (Lansard et al., 2009). The river plume is generally oriented southwestward but eastward currents can occur (up to $18 \%$ of the time) and thus change the direction of the plume (Gatti et al., 2006).

\subsection{In situ oxygen microprofiling: oxygen flux calculation}

Oxygen and resistivity profiles were measured in situ at $200 \mu \mathrm{m}$ resolution by a benthic microprofiler (Unisense ${ }^{\circledR}$ ) equipped with four $\mathrm{O}_{2}$ microelectrodes and one resistivity sensor. The complete description of oxygen profile acquisition is given by Cathalot et al. (2010). Briefly, dissolved oxygen concentration was measured by oxygen microelectrodes (Unisense ${ }^{\circledR}$ ) provided with a built-in reference and an internal guard cathode (Revsbech, 1989). The $\mathrm{O}_{2}$ microsensors had tip outer diameters of $100 \mu \mathrm{m}$, a stirring sensitivity of $<1 \%$, a $90 \%$ response time $<10$ s, and less than $2 \%$ per hour current drift. A linear calibration for the microelectrodes was used between the bottom water oxygen content estimated by Winkler titration (Hansen, 2007) and the anoxic zone of the sediment. The classical method which consists of assigning the interface location to a break in the oxygen concentration gradient was performed on the in situ oxygen microprofiles.

Diffusive oxygen uptake (DOU) was calculated from $\mathrm{O}_{2}$ microprofiles by using the 1-D Fick's first law of diffusion, $J=-\phi D \frac{d C}{d z}$, where $J$ is the flux, $C$ is the concentration, $\phi$ the sediment porosity, and $D$ the molecular diffusion coefficient of oxygen at in situ temperature.

\subsection{Sampling}

Sampling sites were located within $23 \mathrm{~km}$ off the Rhône River mouth with water depths ranging between $24 \mathrm{~m}$ and $89 \mathrm{~m}$ (Table 1). Nine sites were visited during April 2007 (Fig. 1) under moderate discharge conditions (600$\left.1000 \mathrm{~m}^{3} \mathrm{~s}^{-1}\right)$ and low wave significant heights $(<1 \mathrm{~m})$. Bottom water measurements of temperature, salinity, and oxygen concentration were performed on Niskin bottle samples taken $2 \mathrm{~m}$ above bottom. 
Table 1. Sampling sites locations together with sediment oxygen consumption fluxes (TOU), ammonium, and nitrate release to the bottom water measured from core incubation and compared to values estimated by the model. All fluxes are expressed in mmol m $\mathrm{m}^{-2} \mathrm{~d}^{-1}$.

\begin{tabular}{lccccccccccc}
\hline Sites & Lat. & Long. & Depth & Dist & \multicolumn{2}{c}{ TOU } & \multicolumn{2}{c}{ DOU } & \multicolumn{2}{c}{$\mathrm{NH}_{4}^{+}$} & \multicolumn{2}{c}{$\mathrm{NO}_{3}^{-}$} \\
\cline { 7 - 12 } & $\left({ }^{\circ} \mathrm{N}\right)$ & $\left({ }^{\circ} \mathrm{E}\right)$ & $(\mathrm{m})$ & $(\mathrm{km})$ & data & data & model & data & model & data & model \\
\hline $\mathrm{A}$ & $43^{\circ} 18^{\prime} 8$ & $4^{\circ} 51^{\prime} 1$ & 24 & 1.9 & $15.6 \pm 5.0$ & $21.5 \pm 3.9$ & 26.4 & $4.92 \pm 2.89$ & 2.56 & $/$ & 3.94 \\
$\mathrm{~B}$ & $43^{\circ} 18^{\prime} 2$ & $4^{\circ} 50^{\prime} 1$ & 57 & 3 & $15.9 \pm 3.6$ & $15.7 \pm 2.1$ & 18.1 & $0.63 \pm 0.49$ & 0.95 & $0.24 \pm 0.07$ & 0.60 \\
$\mathrm{~K}$ & $43^{\circ} 18^{\prime} 1$ & $4^{\circ} 51^{\prime} 5$ & 62 & 3.3 & $10.2 \pm 2.2$ & $10.8 \pm 2.2$ & 12.1 & $0.32 \pm 0.16$ & 0.45 & $0.21 \pm 0.09$ & 1.02 \\
$\mathrm{~L}$ & $43^{\circ} 18^{\prime} 3$ & $4^{\circ} 52^{\prime} 9$ & 61 & 4 & $11.8 \pm 9.8$ & $7.0 \pm 3.9$ & 10.4 & $2.01 \pm 1.91$ & 0.28 & $0.32 \pm 0.12$ & 0.90 \\
$\mathrm{~N}$ & $43^{\circ} 17^{\prime} 5$ & $4^{\circ} 48^{\prime} 0$ & 65 & 5.5 & $11.4 \pm 2.6$ & $9.5 \pm 1.2$ & 13.9 & $/$ & 0.65 & $0.41 \pm 0.17$ & 0.68 \\
$\mathrm{I}$ & $43^{\circ} 16^{\prime} 0$ & $4^{\circ} 53^{\prime} 0$ & 89 & 7.7 & $10.1 \pm 0.9$ & $4.6 \pm 0.8$ & 7.3 & $/$ & 0.42 & $0.12 \pm 0.08$ & 0.31 \\
$\mathrm{C}$ & $43^{\circ} 16^{\prime} 3$ & $4^{\circ} 46^{\prime} 6$ & 76 & 8.6 & $7.8 \pm 0.6$ & $10.3 \pm 3.2$ & 13.2 & $0.24 \pm 1.29$ & 0.20 & $0.37 \pm 0.08$ & 1.20 \\
$\mathrm{~J}$ & $43^{\circ} 16^{\prime} 1$ & $4^{\circ} 58^{\prime} 1$ & 86 & 12.1 & $9.6 \pm 2.0$ & $7.2 \pm 3.3$ & 8.6 & $/$ & 0.09 & $0.27 \pm 0.09$ & 0.84 \\
$\mathrm{~F}$ & $43^{\circ} 10^{\prime} 0$ & $4^{\circ} 42^{\prime} 0$ & 78 & 21.6 & $7.0 \pm 2.0$ & $5.3 \pm 0.7$ & 6.7 & $/$ & 0.07 & $/$ & 0.55 \\
\hline
\end{tabular}

/: no data. Standard deviations are determined from 2 or 3 cores.

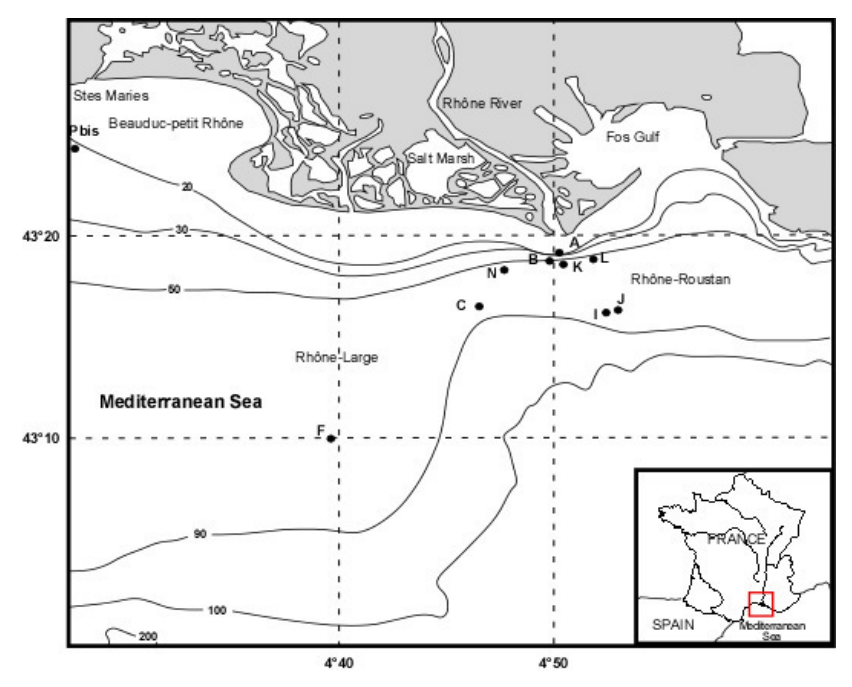

Fig. 1. Sampling sites in the close vicinity of the Rhône River mouth.

Sediment cores from the 9 sites were collected with an Oktopus multicorer $\mathrm{GmbH}$. Up to eight cores of $10 \mathrm{~cm}$ inner diameter were collected at each site with corer penetration depth between 20 and $40 \mathrm{~cm}$. Cores were sampled and maintained at in situ temperature until further analysis. Pore-water and solid phase profiles were sampled on a single core per station: sediments were subsampled under nitrogen atmosphere according to a vertical grid, every $0.5 \mathrm{~cm}$ over the $1 \mathrm{st} \mathrm{cm}$, every $1 \mathrm{~cm}$ over the next $10 \mathrm{~cm}$, and at $2 \mathrm{~cm}$ intervals below. Sediments were then transferred into $50 \mathrm{ml}$ polypropylene Falcon ${ }^{\mathrm{TM}}$ tubes and centrifuged under $\mathrm{N}_{2}$ atmosphere. Pore-waters were extracted and immediately acidified (69\% suprapur $\mathrm{HNO}_{3}^{-}$, Merck) to $\sim \mathrm{pH} 2$ or frozen $\left(-20^{\circ} \mathrm{C}\right)$ depending on the analyses. The sediment solid phase was immediately frozen to keep the anoxic conditions of the sediments.

\subsection{Dark core incubations}

Sediment incubations were performed in the dark on three undisturbed sediment cores per station kept at in situ temperature. Once totally filled and sealed with a gas-proof cap, core tubes were placed in a water bath at in situ bottom temperature $\left( \pm 1^{\circ} \mathrm{C}\right)$. Overlying water into the cores was constantly stirred at about $30 \mathrm{rpm}$ using a Teflon coated magnetic stirring bar attached to the core lid. Magnetic stirrers, centred on the lid of each core, made the stirring bars circulate with the same speed in all the three cores. Every 2-3 h, $50 \mathrm{ml}$ of the overlying water was sampled and replaced with the same volume of filtered bottom water (Hulth et al., 1997). Total fluxes of oxygen, nitrate, and ammonium were then calculated from the difference in concentration between samples in each incubation core, corrected for the replacement water. The incubation period and sampling intervals were adjusted so that oxygen concentration in the overlying water never fell below approximately $70 \%$ from the original ambient value. Incubations typically lasted for $18 \mathrm{~h}$ with sampling intervals of $2-3 \mathrm{~h}$.

\subsection{Solid phase analyses}

Porosity was calculated based on water contents (as assessed by the difference between wet and freeze-dried weight) and assuming a sediment bulk density of $2.65 \mathrm{~g} \mathrm{~cm}^{-3}$. Porosity was corrected for salt content using bottom waters salinities.

Sediment OC contents were assessed on a single core. Corresponding samples were freeze-dried and homogeneously crushed. Precisely weighed subsamples $( \pm 0.001 \mathrm{mg}$ DW) were then analysed in an automatic CHNSThermofisher analyser, after overnight acidification with $8 \%$ $\mathrm{H}_{3} \mathrm{PO}_{4}$ (within the tin cap) to remove carbonates prior to the determination of organic carbon. Another aliquot was analyzed for sulfur content after addition of vanadium pentoxide. Two certified soils (Soil reference material for NCS 
determination, thermo; IHSS 1S101F) were used to check the accuracy of the analyses. Precisions were typically within $2 \%$.

Sequential extraction techniques were used to determine the manganese and iron solid phase concentration, and in particular manganese and iron oxides $\left(\mathrm{MnO}_{\mathrm{x}}\right.$ and $\mathrm{FeO}_{\mathrm{x}}$, respectively). The most reactive manganese and iron oxide fractions (amorphous oxides) were extracted with an ascorbate reagent (Kostka and Luther, 1994; Anschutz et al., 1998, 2000; Haese et al., 2000). This reagent consisted of a deaerated solution of $50 \mathrm{~g}$ of sodium citrate and $50 \mathrm{~g}$ of sodium bicarbonate in 11 of deionized water to which $20 \mathrm{~g}$ of ascorbic acid was slowly added to a final $\mathrm{pH}$ of 8 . About $250 \mathrm{mg}$ of dry sediment was extracted at room temperature with $12.5 \mathrm{ml}$ of this reagent while shaking continuously for $24 \mathrm{~h}$. A second extraction on a separate $250 \mathrm{mg}$ aliquot was carried out with $12.5 \mathrm{ml}$ of $1 \mathrm{~N} \mathrm{HCl}$ for $24 \mathrm{~h}$ to determine acid soluble $\mathrm{Mn}$ and $\mathrm{Fe}\left(\mathrm{Mn}_{\mathrm{HCl}}\right.$ and $\mathrm{Fe}_{\mathrm{HCl}}$, respectively). The centrifuged solutions were then diluted in $0.2 \mathrm{~N} \mathrm{HCl}$ and analysed by flame atomic absorption. The ascorbate reagent selectively extracts amorphous manganese and iron oxides $\left(\mathrm{Mn}_{\mathrm{Asc}}\right.$ and $\mathrm{Fe}_{\mathrm{Asc}}$, respectively) and associated elements (Kostka and Luther, 1994). The reactive phases extracted by $1 \mathrm{~N} \mathrm{HCl}$ represented the operationally defined fraction that comprises amorphous and crystalline $\mathrm{Fe}$ and $\mathrm{Mn}$ oxides, carbonates, and hydrous aluminum silicates (HuertaDiaz and Morse, 1990, 1992). However, it may not have included some iron oxides that are readily converted into sulfides such as goethite and hematite (Raiswell et al., 1994).

\subsection{Pore-water analyses}

Pore-water was analysed for nitrate (Hansen and Koroleff, 2007), ammonia (Helder, 1989), and sulfate (Tabatabai, 1974) using a Quattro-AXFLOW autoanalyser. The acidified subsample was analysed for $\mathrm{Fe}^{2+}$ and $\mathrm{Mn}^{2+}$ by GFAAS using a SOLAAR AAS. Total inorganic carbon (DIC) was measured using a flow injection-conductivity detection system as described in Hall and Aller (1992). Dissolved sulphide $\left(\mathrm{\Sigma H}_{2} \mathrm{~S}\right)$ was determined using the methylene blue method (Cline, 1969).

Oxygen demand units (ODUs), i.e. the amount of oxygen necessary to re-oxidize the reduced products resulting from anaerobic mineralization, were calculated using the concentration of dissolved iron, manganese, and $\mathrm{H}_{2} \mathrm{~S}$ using the following formula: $[\mathrm{ODU}]=\frac{1}{2}\left[\mathrm{Mn}^{2+}\right]+\frac{1}{4}\left[\mathrm{Fe}^{2+}\right]+2\left[\mathrm{~S}^{2-}\right]$ according to the diagenetic equations and the associated stoechiometry (Berner, 1989; Canfield et al., 1993b; Soetaert et al., 1996a), where $\mathrm{S}^{2-}$ stands for $\Sigma \mathrm{H}_{2} \mathrm{~S}$.

\subsection{Diagenetic modeling}

A steady state version of a numerical diagenetic model, OMEXDIA (Soetaert et al., 1996a), as implemented in the open source software R (Soetaert and Herman, 2009), was used and model output was fitted to the measured profiles of oxygen, nitrate, ammonium, ODUs, and OC to estimate the rates of total carbon oxidation, the relative contribution of the major pathways of organic matter mineralization (aerobic, anaerobic, and denitrification), and oxygen utilization.

Briefly, OMEXDIA is a numerical nonlinear coupled model based on the 1-dimensional diagenetic equations (Boudreau, 1997; Berner, 1980). In this model, solutes are transported by molecular diffusion, whereas solid phase compounds are transported by advection, compaction, and bioturbation. The model describes aerobic carbon mineralization (R1), denitrification (R2), manganese and iron reduction (R3), sulphate reduction (R4), nitrification (R5), and the reoxidation by oxygen of anaerobic mineralization reduced products (R6) (Table 2). A list of all the constants used in the model is provided in Table 2. Pastor et al. (2011) demonstrated that in this area, and for this particular campaign, the dominant input of organic carbon was terrestrial, and that it was difficult to characterize the more labile fractions probably responsible for the consumption of the fast pool of organic matter. Consequently, solid phase organic carbon is modelled as 2 fractions with different reactivities (and thus different first-order mineralization rates) and $\mathrm{C} / \mathrm{N}$ ratios corresponding to a labile and a more refractory organic matter. The decomposition kinetics are first-order and thus controlled by two rate constants, corresponding to these two types of organic matter. Model output generates steady state profiles of oxygen, nitrate, ammonium, ODUs, and OC.

Oxygen, nitrate, ammonium, and sediment organic carbon profiles were fitted using an automatic fitting procedure provided by the R package FME (K. Soetaert). Based on previous extensive Monte-Carlo sensitivity analyses (Soetaert et al., 1996a, 1998), the main tuned parameters for this study were (1) the total flux of degradable organic carbon deposited at the surface (Fdeg), (2) its partitioning over a fast and a slow degraded fraction (Pfast), (3) their relative first order degradation constant (Rfast and Rslow, respectively), (4) the asymptotic organic carbon content (OC burial), (5) the nitrification/denitrification constants (Rnit and ksNO3denit), and (6) the burial fraction of reduced species (ODUdepo). For each station, after collinearity among parameters had been checked, a selected set of parameters was then tuned to fit the concentration profiles and fluxes data. Goodness of fit was achieved by minimizing the model cost function which quantifies the discrepancy between observed data and modelled values. High collinearities were found between Fdeg, and both Rnit and pFast: Rnit was then adjusted according to literature and $\mathrm{pFast}$ adjusted manually.

Part of the reduced substances produced during the mineralization of organic matter (here expressed as ODUs) are permanently lost from the system (e.g. by precipitation of FeS and pyrite; Berner, 1977) and manganese carbonate (Pedersen and Price, 1982) below the bioturbation zone. The ODUdepo parameter was then used to account for the disappearance of a certain amount of ODUs out of the system (ODUdepo). 
Table 2. Biogeochemical reactions and parameters/constants used in the model.

\begin{tabular}{|c|c|c|c|c|}
\hline Description & Reaction & \multicolumn{2}{|c|}{ Kinetic formulation } & ID \\
\hline Aerobic respiration & $\mathrm{CH}_{2} \mathrm{O}+\mathrm{O}_{2} \rightarrow \Sigma \mathrm{CO}_{2}+\mathrm{H}_{2} \mathrm{O}$ & \multicolumn{2}{|l|}{ ksO2oxic } & $\mathrm{R} 1$ \\
\hline Denitrification & $\mathrm{CH}_{2} \mathrm{O}+0.8 \mathrm{NO}_{3}^{-}+0.8 \mathrm{H}+\rightarrow \Sigma \mathrm{CO}_{2}+0.4 \mathrm{~N}_{2}+1.4 \mathrm{H}_{2} \mathrm{O}$ & \multicolumn{2}{|c|}{ kinO2denit, ksNO3denit } & R2 \\
\hline $\begin{array}{l}\text { Coupled manganese } \\
\text { and iron reduction }\end{array}$ & $\mathrm{CH}_{2} \mathrm{O}+1$ oxidant $\rightarrow \Sigma \mathrm{CO}_{2}+10 \mathrm{DU}+\mathrm{H}_{2} \mathrm{O}$ & \multicolumn{2}{|c|}{ kinO2anox, kinNO3anox } & R3 \\
\hline Sulfate reduction & $\mathrm{CH}_{2} \mathrm{O}+0.5 \mathrm{SO}_{4}^{2-}+\mathrm{H}^{+} \rightarrow \Sigma \mathrm{CO}_{2}+0.50 \mathrm{DU}+\mathrm{H}_{2} \mathrm{O}$ & \multicolumn{2}{|l|}{$\mathrm{ksSO} 4$} & $\mathrm{R} 4$ \\
\hline Nitrification & $\mathrm{NH}_{4}^{+}+2 \mathrm{O}_{2} \rightarrow \mathrm{NO}_{3}^{-}+\mathrm{H}_{2} \mathrm{O}+2 \mathrm{H}^{+}$ & \multirow{2}{*}{\multicolumn{2}{|c|}{$\begin{array}{l}\text { Rnit, ksO2nitri } \\
\text { rODUox, ksO2oduox }\end{array}$}} & R5 \\
\hline ODU reoxidation & $10 \mathrm{DU}+\mathrm{O}_{2} \rightarrow 1$ oxidant & & & R6 \\
\hline Parameter & Description & Value & Unit & Source \\
\hline ksO2oxic & Half saturation constant for $\mathrm{O}_{2}$ limitation in oxic respiration & 1 & $\mu \mathrm{mol} \mathrm{O} \mathrm{L}^{-1}$ & $\mathrm{~L}$ \\
\hline ksNO3denit & Half saturation constant for $\mathrm{NO}_{3}$ limitation in denitrification & $10-200$ & $\mu \mathrm{mol} \mathrm{NO} \mathrm{L}^{-1}$ & $\mathrm{C}$ \\
\hline $\mathrm{ksSO} 4$ & Half saturation constant for $\mathrm{SO}_{4}$ limitation in sulfate reduction & 800 & $\mathrm{mmol} \mathrm{SO}_{4} \mathrm{~L}^{-1}$ & $\mathrm{~L}$ \\
\hline ksO2nitri & Half saturation constant for $\mathrm{O}_{2}$ limitation in nitrification & 10 & $\mu \mathrm{mol} \mathrm{O} \mathrm{L}^{-1}$ & $\mathrm{~L}$ \\
\hline ksO2oduox & Half saturation constant for $\mathrm{O}_{2}$ limitation in oxidation of reduced product & 1 & $\mu \mathrm{mol} \mathrm{O} \mathrm{L}^{-1}$ & $\mathrm{~L}$ \\
\hline kinO2denit & Half saturation constant for $\mathrm{O}_{2}$ inhibition in denitrification & 1 & $\mu \mathrm{mol} \mathrm{O} \mathrm{L}^{-1}$ & $\mathrm{~L}$ \\
\hline kinO2anox & Half saturation constant for $\mathrm{O}_{2}$ inhibition in anoxic mineralization & 1 & $\mu \mathrm{mol} \mathrm{O} 2 \mathrm{~L}^{-1}$ & $\mathrm{~L}$ \\
\hline kinNO3anox & Half saturation constant for $\mathrm{NO}_{3}$ inhibition in anoxic mineralization & 10 & $\mu \mathrm{mol} \mathrm{NO} \mathrm{L}^{-1}$ & $\mathrm{~L}$ \\
\hline Rnit & Maximum nitrification rate & $4-100$ & $\mathrm{~d}^{-1}$ & $\mathrm{C}$ \\
\hline rODUox & Maximum oxidation rate of oxygen demand units & 20 & $\mathrm{~d}^{-1}$ & $\mathrm{~L}$ \\
\hline $\mathrm{NH}_{4}$ ads & Adsorption coefficient of ammonium & 1.3 & - & $\mathrm{L}$ \\
\hline ODUdepo & Part of ODU production that is deposited as a solid & $97.0-99.5$ & $\%$ & $\mathrm{C}$ \\
\hline
\end{tabular}

C: constrained by experimental data, L: from literature (Soetaert et al., 1996a, Morse et al., 2007)

Bioturbation coefficients, modelled as a local transport process, were adjusted in accordance to literature (Zuo et al., 1991; Radakovitch et al., 1999) and Sediment Profile Imagery (SPI) data performed during the same cruise. Sedimentation rates were obtained from literature (Zuo et al., 1997; et al., 1998, Radakovitch et al., 1999; Miralles et al., 2005). These rates ranged from $10 \mathrm{~cm} \mathrm{yr}^{-1}$ close to the mouth (station A) to $0.1 \mathrm{~cm} \mathrm{yr}^{-1}$ in stations $\mathrm{F}$ and $J$. The mixed layer was averaged to $13 \mathrm{~cm}$ as indicated by the SPI data as developed by Rhoads and Cande (1971) (M. Desmalades personal communication, 2007). C/N values were averaged to 7.1 for the fast fraction and 14.3 for the slow fraction. Diffusivity in water was calculated according to Boudreau (1986) and corrected for salinity, temperature and pressure using the marelac package in R (Soetaert et al., 2010). The bulk sediment diffusion coefficient of solutes was calculated from Rasmussen and Jorgensen (1992) as $D s=\frac{D o}{(1+3(1-\Phi))}$ where $\Phi$ is the sediment porosity and $D o$ is the diffusion coefficient in water as calculated above. All bottom water conditions (temperature, salinity, dissolved elements concentrations) were measured during the sampling cruise.

No change in the sediment texture was clearly observed in this study (visual core observation) and porosity profiles were imposed in the model to account for changes in the sediment pore water content.

\section{Results}

\subsection{Bottom water properties}

Bottom water temperature and salinity were homogeneous among all sites and ranged between 14.2 and $14.9^{\circ} \mathrm{C}$, and between 37.6 and 38.0, respectively. Bottom water was welloxygenated with oxygen saturation between 92 and $100 \%$.

\subsection{Pore-water and solid phase composition}

Pore-water profiles of measured oxygen, nitrate, ammonium, dissolved manganese and iron, sulfate, DIC, and solid phase profiles of particulate manganese and iron for four stations are shown in Fig. 2. Stations A and B are located near the river mouth, while station $\mathrm{F}$ is $23 \mathrm{~km}$ southwestward and station $\mathrm{J}$ is $10.7 \mathrm{~km}$ southeastward (Fig. 1). The oxygen penetration depths ranged from $1.4 \mathrm{~mm}$ at station A to $9.7 \mathrm{~mm}$ at station F. In all cores, a peak of nitrate in the oxic zone was observed from $21 \mu \mathrm{M}$ in site $\mathrm{F}$ to $7 \mu \mathrm{M}$ in site B (Fig. 2). Below the oxic layer, nitrate was then rapidly consumed as indicated by a rapid decrease in nitrate.

Except at station A where the deposition dynamics was highly variable, a decrease in $\mathrm{MnO}_{\mathrm{x}}$ and $\mathrm{FeO}_{\mathrm{x}}$ was observed concomitantly with an increase in $\mathrm{Mn}^{2+}$ and $\mathrm{Fe}^{2+}$. Dissolved manganese and iron concentrations in site A were up to $170 \mu \mathrm{M}$ and $760 \mu \mathrm{M}$, respectively. These concentrations decreased with water depths and distance from the mouth, reaching an average asymptotic value of ca. $25 \mu \mathrm{M}$ of $\mathrm{Mn}^{2+}$ 


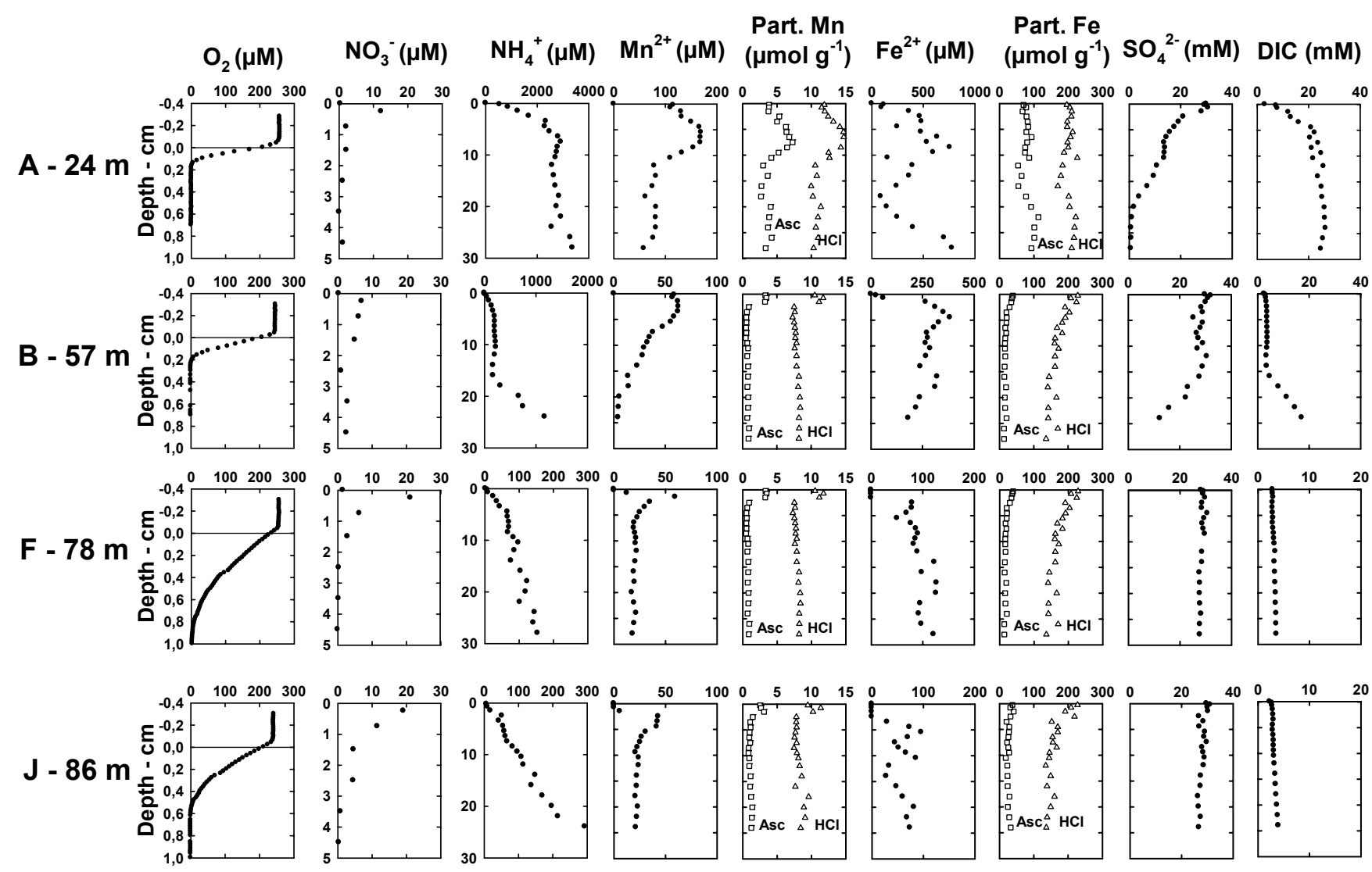

Fig. 2. Biogeochemical profiles in sediments from stations $\mathrm{A}, \mathrm{B}, \mathrm{F}$ and $\mathrm{J}$ : mean oxygen, nitrate, ammonium, dissolved manganese and iron, particulate manganese and iron extracted with $\mathrm{HCl}$ and an ascorbate solution, sulphate and DIC. Note that different scales are used for different stations.

and $100 \mu \mathrm{M}$ of $\mathrm{Fe}^{2+}$ in site F. Similarly, ammonium and DIC concentrations were extremely high at station $\mathrm{A}(\sim 3500 \mu \mathrm{M}$ and $\sim 25 \mathrm{mM}$, respectively) and decreased with water depths and distance from the mouth $\left(<300 \mu \mathrm{M}\right.$ for $\mathrm{NH}_{4}^{+}$and $<5 \mathrm{mM}$ for DIC, at the furthest most stations). In this area, the stock of $\mathrm{Mn}_{\mathrm{Asc}}$ and $\mathrm{Fe}_{\mathrm{Asc}}$ remained available in depth, between 1 and $4 \mu \mathrm{mol} \mathrm{g}^{-1}$ for $\mathrm{Mn}_{\mathrm{Asc}}$, and between 20 and $100 \mu \mathrm{mol} \mathrm{g}^{-1}$ for $\mathrm{Fe}_{\mathrm{Asc}}$.

Sulfate reduction was clearly observable in stations A and B (Fig. 2), and to a lesser extent in stations K, N, and C (data not shown) as indicated by a reduction in sulfate concentrations at depth in the sediment. This decrease was not observed at the other stations, nevertheless high concentrations of $\mathrm{FeO}_{\mathrm{x}}$ could have also promoted a rapid reoxidation of sulfide (produced by sulfate reduction) to sulfate. Despite the reduction of sulfate, pore-water sulfide as measured using colorimetry or microelectrode showed almost no detectable concentration in the micromolar range, down to a depth of $30 \mathrm{~cm}$ (data not shown).

\subsection{Constraining the model with experimental data}

The OMEXDIA model was first applied to represent steady state conditions in low organic flux sediments. It nevertheless had already been used successfully in more productive systems as an eutrophic shallow lagoon in the Mediterranean sea area (Dedieu et al., 2007) and in the Iberian margin (Epping et al., 2002).

The model was run on $40 \mathrm{~cm}$ depth but the first $10 \mathrm{~cm}$ were fitted with highest priority because some non-steady state features can occur at a greater depth (e.g. ammonium profiles, Fig. 2). For all sites of the present study, satisfactory fits were generally obtained over the $40 \mathrm{~cm}$, depth with only the top $10 \mathrm{~cm}$ displayed on Fig. 3. Measured OC profiles did not exhibit an asymptotic shape at all stations and consequently, an accurate fit was not always possible for this variable. The downcore OC content measured around $30 \mathrm{~cm}$ is thus probably a slight overestimation of the asymptotic value. The calculations of OC fluxes derived from these values represent maximum burial efficiencies. Values of the fitted parameters for the nine stations are given in Table 3. 


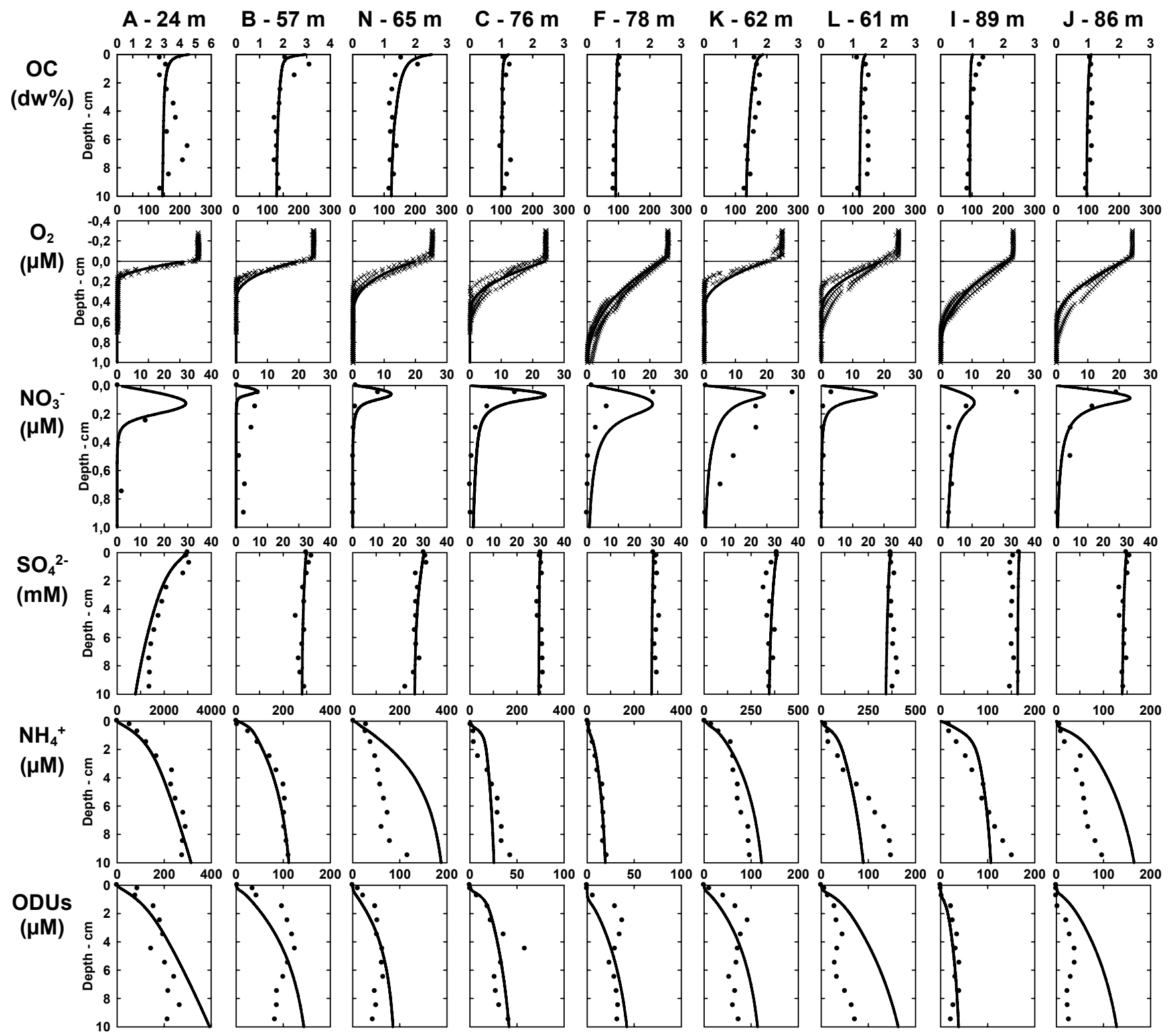

Fig. 3. Experimental profiles (symbols) and the best fit using the steady-state version of OMEXDIA, a numerical coupled diagenetic model (lines) in all sites. Note that different scales are used for different stations.

\subsubsection{Organic carbon deposition and reactivity}

Deposition fluxes of degradable organic carbon and total organic carbon (as defined by degradable OC + buried OC) obtained from modeling gradually decline offshore, along with a decrease in burial efficiency (Fig. 4). Degradable organic carbon fluxes could be up to $657 \mathrm{gC} \mathrm{m}^{-2} \mathrm{yr}^{-1}$ when the accumulation rate reached $10 \mathrm{~cm} \mathrm{yr}^{-1}$ at station $\mathrm{A}$, this value decreasing to $32 \mathrm{gC} \mathrm{m}^{-2} \mathrm{yr}^{-1}$ when the accumulation rate was $0.1 \mathrm{~cm} \mathrm{yr}^{-1}$ (station F). The flux of OC buried in the prodelta area (i.e. stations A and B) accounted for up to $80 \%$ of the total OC flux, this value decreasing offshore to $\sim 20 \%$ in stations $\mathrm{F}$ and $\mathrm{J}$.
The first-order degradation constants were lower in station A $\left(11 \mathrm{yr}^{-1}\right)$ than in the other stations $\left(33 \mathrm{yr}^{-1}\right)$ for the most reactive fraction (Rfast, Table 3). This pattern was not observed for the less reactive fraction (Rslow, Table 3), with no clear spatial pattern and values between $0.21 \mathrm{yr}^{-1}$ and $0.37 \mathrm{yr}^{-1}$ spread among the stations. The proportion of the most labile fraction ranged between $50 \%$ and $94 \%$ (Table 3 ).

\subsubsection{Comparison between model outputs and an independent set of data}

To validate the model, the diffusive fluxes of oxygen, nitrate, and ammonium calculated from the model were compared 
Table 3. Adjusted parameters.

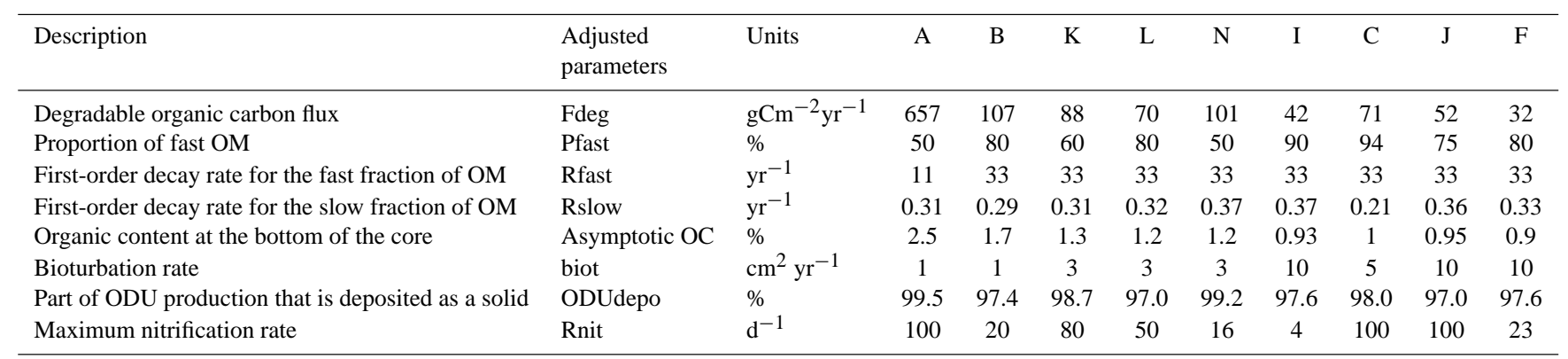

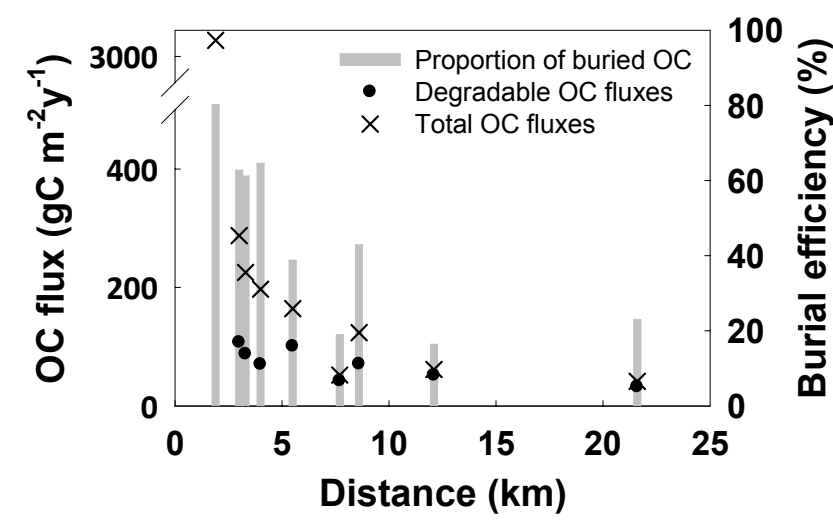

Fig. 4. Flux of degraded $\bullet$ and total $\mathbf{x}$ organic carbon (OC) together with burial efficiency as a function of distance from the Rhône River outlet.

to the benthic fluxes measured in dark core incubations during the same cruise. Both type of fluxes could be reasonably compared as TOU/DOU ratios were generally close to 1 (except for stations $\mathrm{F}$, I, and $\mathrm{J}$ where the ratios were between 1.3 and 1.8, Lansard et al., 2009; Pastor et al., 2011). Results of this comparison are given in Table 1. Oxygen fluxes calculated from the model showed a reasonable agreement with experimental data, showing a decrease with distance from the mouth as previously observed (Cathalot et al., 2010; Lansard et al., 2009). As expected from higher TOU/DOU ratios, DOU estimated from the model at station I, and to a lesser extent at stations $\mathrm{F}$ and $\mathrm{J}$, were lower than TOU measured by core incubations. The ammonium release calculated from the model was also in fair agreement with the core incubations data, whereas nitrate release was slightly overestimated. This overestimation in nitrate release could be due to (1) the coarse resolution of sampling, and/or (2) a contamination with oxygen prior to analysis. Nevertheless, as samples were immediately frozen to avoid such bias, this was probably mainly due to the coarse resolution.

\subsection{Major model outputs}

Oxic OC mineralization rates ranged from $15.7 \mathrm{mmol} \mathrm{C} \mathrm{m}^{-2} \mathrm{~d}^{-1}$ at station B to $4.9 \mathrm{mmol} \mathrm{C} \mathrm{m}^{-2} \mathrm{~d}^{-1}$ at station $\mathrm{F}$ (Table 4). It represents between $8 \%$ and $67 \%$ of the total OC mineralization rates. As expected, the relative proportion of oxic mineralization to total OC mineralization increased with water depth and distance from the mouth (Fig. 5).

Denitrification rates were higher in the vicinity of the river outlet (station A) with a rate of $4.0 \mathrm{mmol} \mathrm{C} \mathrm{m}^{-2} \mathrm{~d}^{-1}$ (Table 4). Further offshore in the continental shelf, these rates decreased to $\sim 0.5 \mathrm{mmol} \mathrm{C} \mathrm{m}^{-2} \mathrm{~d}^{-1}$ at stations $\mathrm{J}$ and F. Relative to total $\mathrm{OC}$ oxidation rates, the denitrification process remained of little importance, with percentages between $2 \%$ and $5 \%$. Station A exhibited the highest values of nitrification, with $7.1 \mathrm{mmol} \mathrm{N} \mathrm{m}^{-2} \mathrm{~d}^{-1}$, while stations offshore exhibited lower values down to $0.4 \mathrm{mmol} \mathrm{N} \mathrm{m}^{-2} \mathrm{~d}^{-1}$.

Anoxic $\mathrm{OC}$ mineralization rates (i.e. the sum of remaining processes: $\mathrm{MnO}_{\mathrm{x}}, \mathrm{FeO}_{\mathrm{x}}$, and sulfate reduction) showed the same trend as the oxic OC mineralization rates, with higher values at station $\mathrm{A}$ of $134.0 \mathrm{mmol} \mathrm{C} \mathrm{m} \mathrm{m}^{-2}$, and values decreasing to $2.0 \mathrm{mmol} \mathrm{C} \mathrm{m}^{-2} \mathrm{~d}^{-1}$ at station F. Figure 5 indicates that the relative part of anoxic and oxic mineralization roughly mirrored one another. The relative contribution of anoxic mineralization processes was $89 \%$ in the prodelta at station $\mathrm{A}$, this percentage decreasing rapidly to a homogeneous steady value around $30-40 \%$ in the adjacent continental shelf and down to $27 \%$ at station $\mathrm{F}$ (Fig. 5). In addition, fitting our $\mathrm{Fe}^{2+}, \mathrm{Mn}^{2+}$, and $\Sigma \mathrm{H}_{2} \mathrm{~S}$ data, high precipitation rates of reduced species were found. The ODUdepo term was then tuned at $99.5 \%$ in station A (Table 3) to allow for the disappearance of ODUs. For all sites, this precipitation term ranged between 97.0 and $99.5 \%$ (Table 3).

Oxygen was preferentially used for oxic mineralization, with a high contribution ranging between 45 and $87 \%$ (Table 4). The remaining fraction was used for nitrification (11$54 \%)$ and for the re-oxidation of reduced products (1-2\%). 
Table 4. Degradation rates of organic carbon by oxic mineralization, denitrification, and anoxic mineralization (in $\left.\mathrm{mmol} \mathrm{C}^{-2} \mathrm{~d}^{-1}\right)($ left); and the relative contribution to the oxygen consumption by oxic mineralization, nitrification, and ODUs reoxidation (in \%) (right).

\begin{tabular}{|c|c|c|c|c|c|c|}
\hline \multirow[t]{2}{*}{ Sites } & \multicolumn{3}{|c|}{$\begin{array}{l}\text { Organic carbon degradation processes } \\
\qquad\left(\mathrm{mmolC} \mathrm{m}^{-2} \mathrm{~d}^{-1}\right)\end{array}$} & \multicolumn{3}{|c|}{$\begin{array}{l}\text { Relative use of oxygen } \\
\qquad(\%)\end{array}$} \\
\hline & Oxic mineralization & Denitrification & Anoxicmineralization & Oxic mineralization & Nitrification & ODU reoxidation \\
\hline A & 12.0 & 4.0 & 134.0 & 45.4 & 53.9 & 0.7 \\
\hline B & 15.7 & 0.7 & 8.2 & 86.5 & 12.6 & 0.9 \\
\hline K & 9.2 & 0.5 & 10.3 & 76.0 & 23.0 & 1.0 \\
\hline $\mathrm{L}$ & 7.1 & 0.8 & 8.1 & 68.8 & 29.1 & 2.1 \\
\hline $\mathrm{N}$ & 11.6 & 0.6 & 10.8 & 83.2 & 16.2 & 0.6 \\
\hline I & 6.4 & 0.1 & 3.1 & 87.6 & 11.4 & 1.0 \\
\hline $\mathrm{C}$ & 9.4 & 0.9 & 5.9 & 70.8 & 28.4 & 0.8 \\
\hline $\mathrm{J}$ & 5.7 & 0.6 & 5.4 & 66.9 & 31.3 & 1.8 \\
\hline $\mathrm{F}$ & 4.9 & 0.4 & 2.0 & 74.0 & 25.2 & 0.8 \\
\hline
\end{tabular}

\section{Discussion}

The Rhône River prodelta area is a highly dynamic system, mainly driven by the river discharge and meteorological events, which lead to episodic supply of sediment, resuspension, and erosion events in the prodelta (sites located above $40 \mathrm{~m}$ depth). In this area, the succession of small deposition events (few cm, such as the ones documented in Drexler and Nittrouer, 2008 and Marion et al., 2010) and major events (Miralles et al., 2006) induces a series of non-steady-state features. Therefore, the assumption of steady-state conditions in such a system is questionable. These changes in stratigraphy are partially to totally smoothed due to sediment reworking (Drexler and Nittrouer, 2008). Also, previous studies in this area showed no significant variations of DOU rates in the continental shelf (further than $10 \mathrm{~km}$ from the river mouth) through time during "non-flood" conditions (Cathalot et al., 2010 and references therein). Several weeks before and during our sampling period (April 2007), water discharges were below average annual values $\left(1700 \mathrm{~m}^{3} \mathrm{~s}^{-1}\right)$ and this period was assumed to be representative of an average functioning of the system. Thus, we believe that the assumption of steady-state for periods outside major flood is reasonable. Consequently, the present study focuses only on "non-flood" conditions and is a first step to a better understanding of the benthic biogeochemistry in this highly dynamic system.

\subsection{Organic carbon reactivity}

The degradable organic carbon deposited at the sediment surface is composed of a range of OM reactivities (Wakeham et al., 1997). This is represented in the OMEXDIA model by two distinct fractions: a labile fraction and an intermediate reactivity fraction (Soetaert et al., 1996a). These two fractions are represented by a first-order degradation con- stant which is characteristic of their reactivity. The values obtained in this study (11-33 $\mathrm{yr}^{-1}$ and $\left.0.21-0.37 \mathrm{yr}^{-1}\right)$ were comparable to those of $18 \mathrm{yr}^{-1}$ and $1.1 \mathrm{yr}^{-1}$ (normalized to a temperature of $15^{\circ} \mathrm{C}$ using a $Q_{10}$ of 2 reported in Westrich and Berner (1984) from incubation experiments of fresh planktonic material). While the labile fraction of $\mathrm{OM}$ has a degradation constant close to fresh planktonic material, the first-order degradation constants for the less reactive material could correspond to resuspended organic matter, which could explain the low degradation constant observed (Berner, 1980; Hargrave and Phillips, 1989; Herman et al., 2001). Measurements of phytoplankton biomass showed very low Chl- $a$ levels in the water column (estimated by low fluorescence levels in CTD profiles - J. J. Naudin, personal communication, 2008) during our sampling cruises in the studied area (April 2007, September 2007, June 2008, December 2008) and during other pelagic cruises (May 2008, 2009). Furthermore, prodelta sediments are mainly composed of terrigenous OM as evidenced by their $\delta^{13} \mathrm{C}$ values of $-27 \%$ (Lansard et al., 2009). This fast decaying fraction most likely represents reactive material of either riverine or marine phytoplanktonic origin, not accessible with classical bulk measurements as previously described by Pastor et al., (2011).

The two fractions of OM here are then related to the dilution of the Rhône River material (Tesi et al., 2007; Lansard et al., 2009). OM in stations A and B, located in the prodelta, is a mixture of fine and coarse continental material rich in sedimentary organics. These stations present $\delta^{13} \mathrm{C}$ depleted values characteristic of terrestrial inputs together with an apparent labile fraction of OM. Further offshore, OM is composed of aged resuspended particles which underwent many deposition/degradation/remobilization cycles and characterized by lower OC, "heavier" isotopic composition and the absence of lignin (Lansard et al., 2009). 

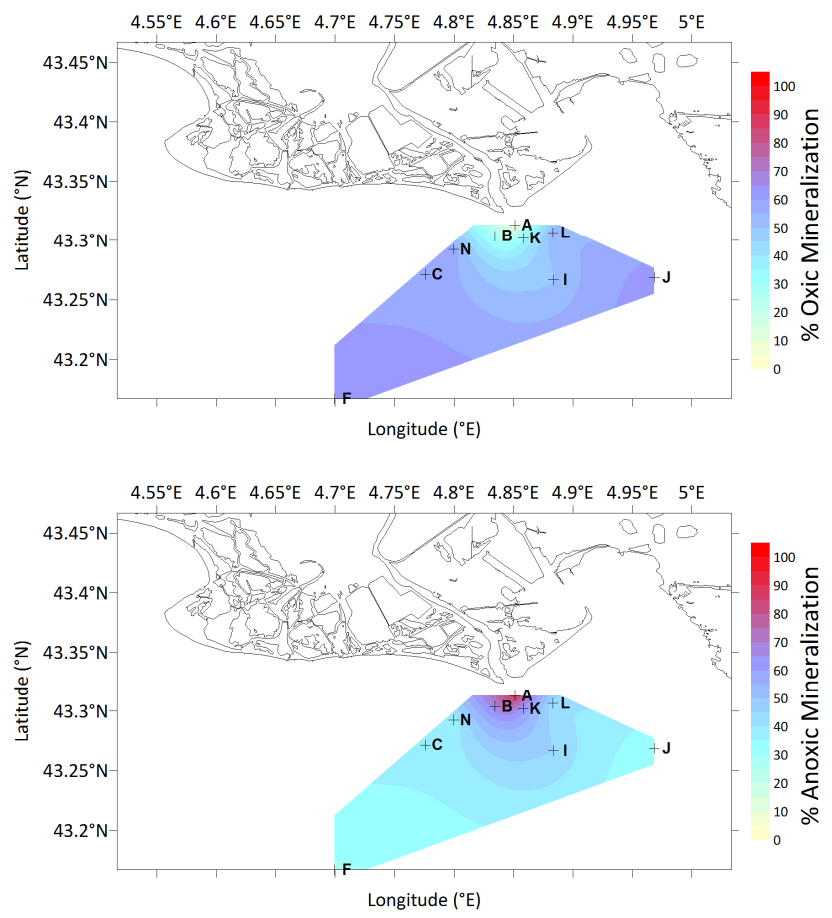

Fig. 5. Relative contribution of principal organic carbon mineralization pathways (oxic mineralization and anoxic mineralization) on total organic carbon mineralization expressed in \% in the Rhône River prodelta and its adjacent continental shelf. Denitrification process accounted for less than $6 \%$.

\subsection{Mineralization processes}

The highest values of fluxes of degradable organic carbon (Table 3) are found at stations located in the prodelta. This reflects the spatial distribution of OC oxidation processes from modeling (Fig. 5). Our high OC deposition fluxes are higher than the previous estimation of $178 \mathrm{gC} \mathrm{m}^{-2} \mathrm{yr}^{-1}$ for POC deposition in the whole prodelta reported by Durrieu de Madron et al. (2000). This difference is likely related to the surface area of the zone studied: our station A is directly located within the prodelta characterized by high sedimentation rates (up to $41 \mathrm{~cm} \mathrm{yr}^{-1}$ ). Durrieu de Madron et al. (2000) based their calculation on a wider area including more distal stations (our stations $\mathrm{B}, \mathrm{N}$, and $\mathrm{K}$ ) where the sedimentation rates gradient is maximal. The high $\mathrm{OC}$ deposition fluxes observed within the prodelta are likely responsible for the high mineralization rates in this area. Oxygen is thus rapidly consumed within the sediments and anoxic processes become the dominant processes (Fig. 5).

At stations located further on the adjacent continental shelf, values of $30-100 \mathrm{gC} \mathrm{m}^{-2} \mathrm{yr}^{-1}$ (Table 3) are close to the ones reported in Canfield (1989) who found carbon oxidation rates between ca. $20 \mathrm{gC} \mathrm{m}^{-2} \mathrm{yr}^{-1}$ and $110 \mathrm{gC} \mathrm{m}^{-2} \mathrm{yr}^{-1}$ for a similar accumulation rate of $0.1 \mathrm{~cm} \mathrm{yr}^{-1}$. Then, as the distance from the river outlet increases, mineralization rates become lower (Table 4), oxygen

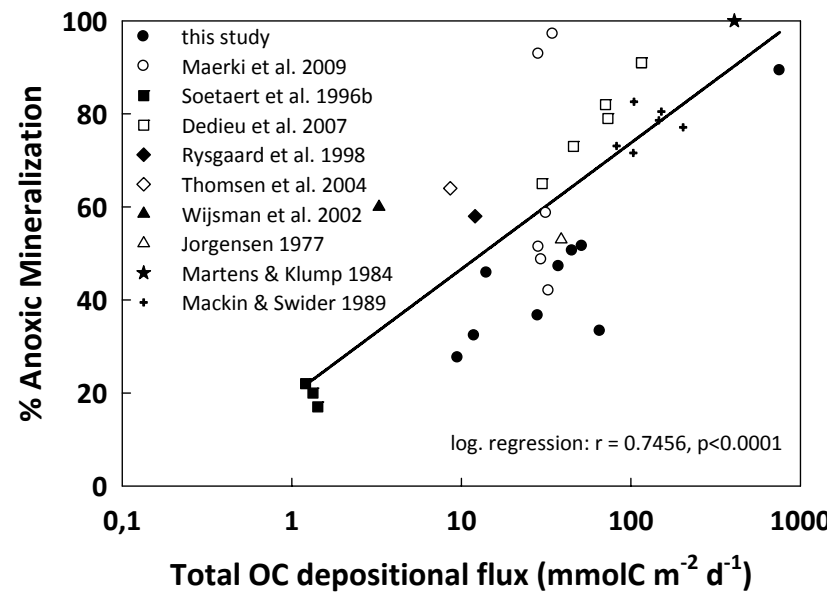

Fig. 6. Contribution of anoxic processes in total OC mineralization as a function of total OC depositional flux for the Rhône River prodelta and its adjacent continental shelf (this study) and a compilation of several data.

penetration depths increase and a progressive dominance of oxic processes takes place (Fig. 5).

This decrease of mineralization rates shows the same pattern than the variation of sedimentation rate as previously observed in other studies (i.e. Canfield, 1989; Tromp et al., 1995). The burial of organic carbon within the prodelta is very high and represents up to $80 \%$ of the total OC flux, this value decreasing offshore to ca. $20 \%$ in stations $\mathrm{F}$ and $\mathrm{J}$. For instance, Henrichs and Reeburgh (1987) reported a carbon burial efficiency of up to $80 \%$ for a sedimentation rate of $10 \mathrm{~cm} \mathrm{yr}^{-1}$, and ca. $5-20 \%$ for a sedimentation rate of $0.1 \mathrm{~cm} \mathrm{yr}^{-1}$.

In order to better assess the controls of benthic OC degradation, we plotted the relative contribution of anoxic processes in OC mineralization as a function of the logarithm of total OC deposition flux of various sediment systems (Fig. 6). There is a significant correlation $(n=35, r=0.74$, $p<0.0001)$ between the percentage of anoxic mineralization and the logarithm of total OC deposition flux, the highest anaerobic contribution to $\mathrm{OC}$ mineralization occurring in regions with the highest $\mathrm{POC}$ rain. This is also visible in our sulfate profiles: the most significant consumption (and likely the highest sulfate reduction rates) occurs in stations with maximal accumulation rate. Hargrave et al. (2008) also evidenced an enhancement of microbial sulfate reduction under conditions of high organic matter sedimentation and the progressive formation of suboxic-anoxic conditions. Our results thus suggest that the amount of POC vertically exported, and reaching the coastal seafloor, directly controls the anaerobic mineralization activity and carbon preservation of oceanic sediments (Henrichs and Reeburgh, 1987; Canfield, 1994). The control of OC mineralization by POC rain provides then a critical positive relationship between the burial of reduced materials in sediments and the OC inputs in ocean margins. 


\subsection{Behaviour of reduced products}

\subsubsection{Insights on iron and sulfur cycles}

Our modeling results clearly show that anoxic mineralization processes play a major role in the Rhône River prodelta, providing crucial information about the OC cycle in this coastal area. The OMEXDIA model considers all anoxic mineralization processes as a single process leading to the ultimate release of ODUs. Accordingly, the model does not give any insights on the reaction pathways of anaerobic oxidation nor on the benthic biogeochemical cycles of the elements involved. For instance, at some stations and within the limited coring depth (A and B, and to a lower extent, $\mathrm{K}, \mathrm{N}$, and $\mathrm{C}$ ), sulfate reduction is most likely to occur as indicated by a visible decrease in sulfate concentration in the lower sedimentary column (Fig. 2, stations K, N, and C not shown). Then, for instance at station $\mathrm{B}$, with no precipitation (pdepo $=0$ ), the model generates a production of $5 \mathrm{mmol} \mathrm{m}^{-2} \mathrm{~d}^{-1}$ of ODU, whereas the $\mathrm{SO}_{4}^{2-}$ profile allows the calculation using the PROFILE software program (Berg et al., 1998) of a production of $10 \mathrm{mmol} \mathrm{m}^{-2} \mathrm{~d}^{-1}$ of ODU expressed as $\Sigma \mathrm{H}_{2} \mathrm{~S}$. These two numbers are within the same order of magnitude and confirm that sulfate reduction is a major process at station B. The feature is slightly different at station A, where the model generates a production of $67 \mathrm{mmol} \mathrm{m}^{-2} \mathrm{~d}^{-1}$ of ODU, versus $20 \mathrm{mmol} \mathrm{m}^{-2} \mathrm{~d}^{-1}$ of ODU $\left(\mathrm{SO}_{4}^{2-}\right.$ profile) expressed as $\Sigma \mathrm{H}_{2} \mathrm{~S}$. This overestimation could be due to other mineralization processes not included in the model. For instance, Garcia-Garcia et al. (2006) showed evidence for high rates of methanogenesis within the Rhône prodelta area after the rapid deposition of a thick layer of new sediment. As no measurements of $\mathrm{CH}_{4}$ were performed during our study, this hypothesis cannot be confirmed, but is nevertheless not excluded. This part of the discussion will therefore be principally based on the sulfate reduction process.

Since we observed sulfate reduction but no sulfide accumulation, especially near the river outlet, it is likely that sulfide is being removed from pore-water through reactions within the anoxic zone, such as FeS precipitation (Berner, 1977; Westrich and Berner, 1984).

The large value of the precipitation term indicates a substantial precipitation of reduced species ( $>99 \%$ at station A), supporting this sulfide precipitation hypothesis. Although such precipitation rates are in the upper range of reported literature data (Chanton et al., 1987; Jorgensen et al., 1990), this "output" term of the model is supported by our data. Indeed, the ODUdepo term can be substantiated by the observed $\mathrm{C} / \mathrm{N}$ ratios $\left(\triangle \mathrm{DIC} / \Delta \mathrm{NH}_{4}^{+}\right)$in pore-water at all the stations. The general equation of oxidation of organic matter producing ODUs in Soetaert et al. (1996a) is expressed as:

$$
\begin{aligned}
& \left(\mathrm{CH}_{2} \mathrm{O}\right)_{\mathrm{x}}\left(\mathrm{NH}_{3}\right)_{\mathrm{y}}\left(\mathrm{H}_{3} \mathrm{PO}_{4}\right)+1 \text { oxidant } \rightarrow \mathrm{xCO}_{2}+\mathrm{yNH}_{3} \\
& +\mathrm{H}_{3} \mathrm{PO}_{4}+\mathrm{xODU}+\mathrm{xH}_{2} \mathrm{O}
\end{aligned}
$$

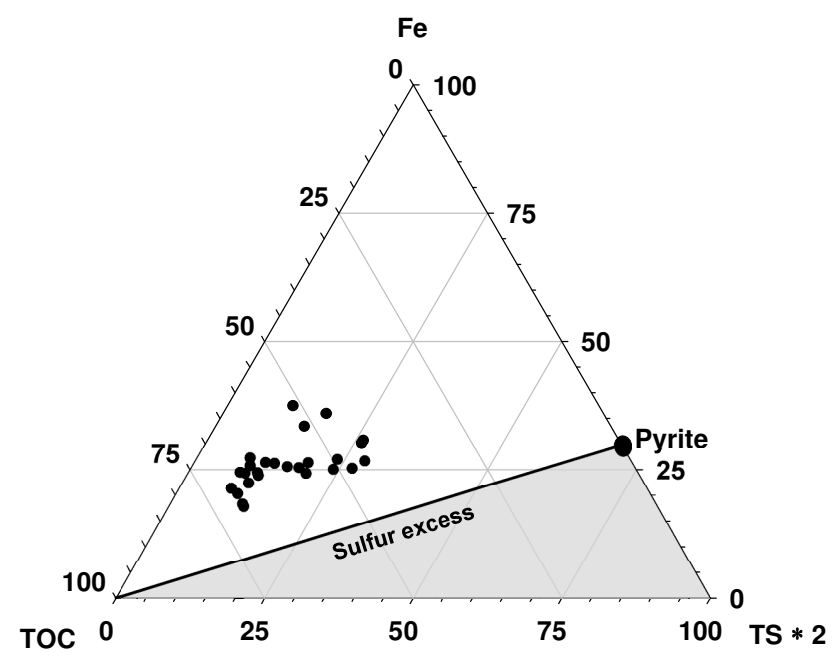

Fig. 7. Ternary plot of carbon-iron-sulfur relationship. The shaded area represents the field where iron is limiting. Sulfur was multiplied by 2 (2 moles of $\mathrm{C}$ produce 1 mole of $\mathrm{S}$ ). Iron was determined from solid extraction with $\mathrm{HCl}$. Data are from stations A and $\mathrm{K}$.

Then, the ODU/ $\mathrm{NH}_{4}^{+}$ratio in the model reflects the $\mathrm{C} / \mathrm{N}$ ratio of the degraded organic matter. The $\mathrm{C} / \mathrm{N}$ of the fast fraction is 7.1 and the $\mathrm{C} / \mathrm{N}$ of the slow fraction is 14.3. According to their relative proportion (Pfast, 1-Pfast, Table 3), it is then possible to calculate the average $\mathrm{C} / \mathrm{N}$ ratio of the degradable fraction. Therefore, the slope of the plot of measured ODU $\left(\mathrm{Fe}^{2+}, \mathrm{Mn}^{2+}\right.$, and $\left.\mathrm{\Sigma H}_{2} \mathrm{~S}\right)$ against $\mathrm{NH}_{4}^{+}$, corrected for diffusion coefficients, gives the $\mathrm{C} / \mathrm{N}$ ratio in pore-water at each station. The difference between the estimated theoretical $\mathrm{C} / \mathrm{N}$ ratios without any precipitation in the system from the modeling and $\mathrm{C} / \mathrm{N}$ ratios from the measured data is that the later gives the proportion of ODU which is precipitated. In station $\mathrm{A}$ for instance, the estimated $\mathrm{C} / \mathrm{N}$ ratio from porewater is 0.09 vs. 7.82 for the degradable OM (modeling). This means that $\sim 99 \%$ of the produced ODUs are missing from the solute phase. Therefore, both our measured data and modeling results suggest an intense precipitation of reduced species, and most likely an important recombination of the sulfides produced through sulfate reduction.

To estimate possible limitations of FeS formation, the relative amounts of organic carbon, sedimentary sulfur and iron were plotted in a ternary diagram (Fig. 7; Littke et al., 1991; Luckge et al., 1999). The area below the line reflects ironlimiting conditions whereas, above, pyrite formation can be limited by the availability of sulfate or organic matter. All sediments from the Rhône prodelta area fall above this line indicating that the sediment contains enough iron to form pyrite through sulfide oxidation. Regarding the high amounts of organic carbon in the system and the high sulfate availability in the water column, it is likely that a large quantity of reducible iron limits the occurrence of sulfide-rich porewaters in the Rhône River prodelta sediments. Another efficient 
reaction pathway for the disappearance of $\mathrm{\Sigma H}_{2} \mathrm{~S}$ is manganese and/or iron reduction coupled to partial sulfide oxidation. This process could explain the residual concentration of $\mathrm{Fe}^{2+}$ at depth (Fig. 2) and the very low concentration of $\Sigma \mathrm{H}_{2} \mathrm{~S}$. Our results clearly show that neither $\mathrm{Fe}^{2+}$ nor particulate iron are limiting. In addition, iron monosulfide (FeS) and Pyrite $\left(\mathrm{FeS}_{2}\right)$ generally represent the major part of reduced inorganic sulfur pools in marine sediments (Berner, 1984; King et al., 1985; Thamdrup et al., 1994).

The retention of freshly produced sulfide varies from one system to another, $10 \%$ to $77 \%$ being buried in coastal marine sediments (Chanton et al., 1987; Jorgensen et al., 1990). In the case of the highly reduced sediments of the Rhône River prodelta, this retention is thus likely to be very efficient with values higher than $77 \%$. Hedges and Keil (1995) already pointed out that the introduction of greater amounts of labile marine OM could drive the redox environments of deltaic and slope sediments on to sulfate reduction, halting then the iron and manganese-based degradation when these metals are precipitated as insoluble, reduced sulfides. Our results suggest that the terrestrial OM delivered by the Rhône River, constituted of a reactive fraction, also pushes the diagenetic system towards the burial of major reduced products. Under some depositional/diagenetic regimes, coastal sediments have been evidenced to have a reactive sulphur fraction without significant net addition to this sulphur pool, evidencing important precipitation of reduced sulfides (see Bottrell et al., 2009 and references therein). In addition, the sudden burial by several centimetre of flood sediments is likely to play a major role on anoxic mineralization processes in prodelta sediments and the preservation of reduced compounds (Thamdrup and Dalsgaard, 2000; Quintana et al., 2007). The quality and quantity of river discharge rates (in terms of nutrients, OM, and metal oxides) might therefore predispose the deltaic regions toward different redox regimes, and consequently toward contrasting carbon preservation and reduced species burial efficiencies. Deltaic areas could thus be major centres for burial of reduced diagenetic products, in addition to be major deposit centres for OM (Hedges and Keil, 1995). More investigation is needed to determine the quantitative importance of such processes. Indeed, incorporating such significant storage of reduced species in deltaic areas could have an impact on models of global Fe-S-C cycling. In a further step, the use of a more detailed model of early diagenesis would allow a better constrain of these anoxic processes.

\subsubsection{Impact on the oxygen consumption}

This intense cycling and removal of reduced substances explains the small amount of oxygen used to re-oxidize reduced products (Table 4). Between 62 and $93 \%$ of the total $\mathrm{O}_{2}$ consumption were used directly for the oxidation of organic carbon (Table 4), the rest was used for the re-oxidation of reduced products and nitrification. An interesting feature of this RiOMar system is the low fraction of oxygen flux associated to the re-oxidation of reduced chemical species such as $\mathrm{Fe}^{2+}, \mathrm{Mn}^{2+}$, or sulfide (1-3\%). Because more than $97 \%$ of the ODU originally produced are precipitated at depth as indicated by the ODUdepo term (Table 3), the resulting flux toward the oxic layer is consequently very low. In other studies, the relative contribution of the $\mathrm{O}_{2}$ uptake by the sediment for the re-oxidation of reduced products is generally higher. Kasih et al. (2009) showed that $47 \%$ of the total $\mathrm{O}_{2}$ consumption was directly used in the $\mathrm{OM}$ mineralization, $19 \%$ for nitrification, and $34 \%$ for the re-oxidation of reduced products in the Ago Bay sediments (Japan). Berg et al. (2003) reported an $\mathrm{O}_{2}$ contribution of $40 \%$ for OM mineralization, $12 \%$ for nitrification, and $48 \%$ for re-oxidation of reduced products in arctic marine sediment. A large difference in ammonium concentrations and mineralization rates exists between these studies and the present one. While $\mathrm{NH}_{4}^{+}$concentrations at depth are below $100 \mu \mathrm{M}$ in Kasih et al. (2009) and below $80 \mu \mathrm{M}$ in Berg et al. (2003), they can be up to $\sim 3500 \mu \mathrm{M}$ in station A and remain below $250 \mu \mathrm{M}$ only at the far station (station F). Similarly, the DIC concentration is also very high with up to $\sim 25 \mathrm{mM}$ at station A.

Our results highlight that oxygen consumption rates in the Rhône River system are mainly related to aerobic mineralization. The re-oxidation of reduced products does not contribute significantly to oxygen consumption. This is also clear by the smooth gradual decrease of oxygen towards 0 ; if important oxygen consumption would take place at the oxicanoxic interface, oxygen would disappear much more drastically there (Fig. 3). This leads to a major conclusion concerning the use of dissolved oxygen fluxes to estimate total carbon mineralization rates. Table 5 shows the model output versus the calculated carbon mineralization rates using in situ dissolved oxygen fluxes and Redfield ratio $\left(\mathrm{O}_{2} / \mathrm{C}=138 / 106\right)$. At station $\mathrm{A}$, the difference is maximal with a carbon mineralization rate of $657 \mathrm{gC} \mathrm{m}^{-2} \mathrm{yr}^{-1}$ derived from modeling versus only $72 \mathrm{gC} \mathrm{m}^{-2} \mathrm{yr}^{-1}$ as derived from oxygen profiles, leading to an underestimation of around $89 \%$ at this site. This difference is of course lower when anoxic processes and removal of ODU are less important, with an underestimation of around $44 \%$ at station F. Thus, in the Rhône River prodelta where precipitation of reduced products are linked to anoxic processes displaying very large rates in the sediment column, oxygen is uniquely used for oxic mineralization and nitrification (Table 4). Therefore, the use of dissolved oxygen fluxes as a proxy for carbon mineralization should be used with caution in other RiOMar systems and coastal areas with similar sediment biogeochemistry.

\section{Concluding remarks}

Mineralization processes that occur in the Rhône prodelta and its adjacent continental shelf are mainly driven by the OM inputs. Our results evidence a close relationship between 
Table 5. Carbon mineralization rates as calculated from (1) modeling and (2) in situ oxygen microprofiling. Units are $\mathrm{gCm}^{-2} \mathrm{yr}^{-1}$.

\begin{tabular}{ccc}
\hline Sites & $\begin{array}{c}\text { Carbon mineralization } \\
\text { from modeling }\end{array}$ & $\begin{array}{c}\text { Carbon mineralization } \\
\text { from oxygen profiles }\end{array}$ \\
\hline A & 657 & $72 \pm 13$ \\
B & 107 & $53 \pm 7$ \\
K & 88 & $36 \pm 7$ \\
L & 70 & $24 \pm 13$ \\
N & 101 & $32 \pm 4$ \\
I & 42 & $15 \pm 3$ \\
C & 71 & $35 \pm 11$ \\
J & 52 & $24 \pm 11$ \\
F & 32 & $18 \pm 2$ \\
\hline
\end{tabular}

$\mathrm{OM}$ inputs and anaerobic mineralization processes. These inputs, mainly terrestrial, originate from the Rhône River and are composed of a significant fraction of reactive material with degradation constants close to fresh phytoplankton. High deposition of more labile material close to the river is responsible for a rapid consumption of oxygen and an intense OM degradation, mainly driven by anoxic processes. In the adjacent continental shelf, this predominance of anoxic processes decreases together with the decrease in organic carbon deposition, accumulation rates, and the increase of oxygen exposure time.

Our modeling results suggest a major contribution of precipitation processes in the Rhône River prodelta sediments. Sulfate reduction in the river outlet is most likely to be the main anoxic process (although methanogenesis is not excluded) and retention of produced sulfide appears to be very efficient with more than $97 \%$ of produced reduced species disappearing from the pore water. This could be associated to (1) the precipitation of $\mathrm{FeS}$ or/and $\mathrm{FeS}_{2}$ and to (2) secondary reactions as, for instance, the re-oxidation of sulfide by Fe-oxides or Mn-oxides. This intense cycling reduces the diffusion of reduced species to the oxic zone, thus limiting the contribution of oxygen flux in the re-oxidation of these products. More insight is however needed on the reaction pathways occurring in this area to better define the metal cycling as well as the contribution of $\mathrm{Mn}$ and Fe reduction processes.

Nevertheless, our study clearly highlights the importance of secondary precipitation reactions in RiOMar systems. Our estimations for the Rhône River system draw attention to the need for assessing and quantifying the burial of precipitated reduced species, especially when trying to assess some sedimentary $\mathrm{C}$ budgets in these highly reactive areas.
Acknowledgements. We would like to thank the captain and crew of the R.V. Tethys II (CNRS-INSU) and the entire scientific crew of the CHACCRA-RiOMar.Fr cruises for their technical assistance during sample collection. We also thank Bruno Blombled, Amaury Gaillard, Laure Sandoval, Hassiba Lazar for analytic assistance and Pascal Lecroart for modeling assistance. The modeling was performed after two short stays (1 week) by the two first authors at NIOOCEME. This work was performed jointly by LGE and LSCE during the Ph.D thesis advised by E. Viollier and B. Deflandre for Lucie Pastor and C. Rabouille for Cécile Cathalot. This work was funded by the French national ANR program CHACCRA (contract number ANR-VULN-06-001-01) and the French INSU-EC2CO program RiOMar.fr.

It is the IPGP contribution \#3156 and LSCE contribution number \#4423.

Edited by: J.-J. Naudin

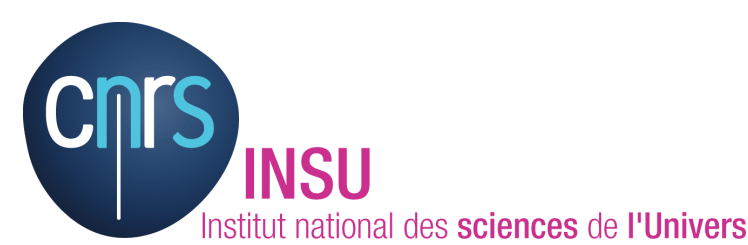

The publication of this article is financed by CNRS-INSU.

\section{References}

Aller, R. C., Blair, N. E., Xia, Q., and Rude, P. D.: Remineralization rates, recycling, and storage of carbon in Amazon shelf sediments, Cont. Shelf Res., 16, 753-786, 1996.

Aloisi, J. C., Cambon, J. P., Carbonne, J., Cauwet, G., Millot, C., Monaco, A., and Pauc, H.: Origin and role of the bottom nepheloid layer in the tranfer of particles into the marine environment - application to the gulf of lions, Oceanol. Acta, 5, 481-491, 1982.

Anschutz, P., Zhong, S. J., Sundby, B., Mucci, A., and Gobeil, C.: Burial efficiency of phosphorus and the geochemistry of iron in continental margin sediments, Limnol. Oceanogr., 43, 53-64, 1998.

Anschutz, P., Sundby, B., Lefrancois, L., Luther, G. W., and Mucci, A.: Interactions between metal oxides and species of nitrogen and iodine in bioturbated marine sediments, Geochim. Cosmochim. Ac., 64, 2751-2763, 2000.

Antonelli, C., Provansal, M., and Vella, C.: Recent morphological channel changes in a deltaic environment. The case of the $\mathrm{Rh}^{\wedge}$ one River, France, Geomorphology, 57, 385-402, 2004.

Berelson, W. M., Hammond, D. E., and Cutter, G. A.: In situ measurements of calcium carbonate dissolution rates in deep-sea sediments, Geochim. Cosmochim. Ac., 54, 3013-3020, 1990.

Berg, P., Risgaard-Petersen, N., and Rysgaard, S.: Interpretation of measured concentration profiles in sediment pore water, Limnol. Oceanogr., 43(7), 1500-1510, 1998.

Berg, P., Rysgaard, S., and Thamdrup, B.: Dynamic, modeling of early diagenesis and nutrient cycling, A case study in an arctic marine sediment, Am. J. Sci., 303, 905-955, 2003. 
Berner, R. A.: Stoichiometric models for nutrient regeneration in anoxic sediments, Limnol. Oceanogr. 22, 781-786, 1977.

Berner, R. A.: Early Diagenesis: A Theoretical Approach. Princeton Series in Geochemistry, edited by: Princeton, N. J., Princeton University Press, Princeton, 241 pp., 1980.

Berner, R. A.: Sedimentary pyrite formation: An update, Geochim. Cosmochim. Ac., 48(4), 605-615, 1984.

Berner, R. A.: Biogeochemical cycles of carbon and sulfur and their effect on atmospheric oxygen over phanerozoic time, Global Planet. Change, 75, 97-122, 1989.

Berner, E. K. and Berner, R. A.: Global environments: Water, Air and Geochemical cycles, Prentice-Hall: Upper Saddle River, NJ, 1996.

Boudreau, B. P.: Mathematics of tracer mixing in sediments. 1. Spatially-dependent, diffusive mixing, Am. J. Sci., 286, 161198, 1986.

Boudreau, B. P.: Modeling the sulfide-oxygen reaction and associated $\mathrm{pH}$ gradients in porewaters, Geochim. Cosmochim. Ac., 55, 145-159, 1991.

Boudreau, B. P.: Diagenetic models and their implementation: Modeling transport and reactions in aquatic sediments, SpringerVerlag, Heidelberg, 414 pp., 1997.

Borges, A. V.: Do we have enough pieces of the jigsaw to integrate $\mathrm{CO} 2$ fluxes in the coastal ocean?, Estuaries, 28, 3-27, 2005.

Buscail, R., Pocklington, R., and Germain, C.: Seasonal variability of the organic-matter in a sedimentary coastal environment sources, degradation and accumulation (continental shelf of the Gulf-of-Lions, Northwestern Mediterranean-Sea), Cont. Shelf Res., 15, 843-869, 1995.

Canfield, D. E.: Sulfate reduction and oxic respiration in marine sediments: implications for organic carbon preservation in euxinic environments, Deep-Sea Res. Pt. I, 36, 121-138, 1989.

Canfield, D. E.: Factors influencing organic carbon preservation in marine sediments, Chem. Geol., 114, 315-329, 1994.

Canfield, D. E. and Berner, R. A.: Dissolution and pyritization of magnetite in anoxic marine sediments, Geochim. Cosmochim. Ac., 51, 645-659, 1987.

Canfield, D. E., Jorgensen, B. B., Fossing, H., Glud, R., Gundersen, J., Ramsing, N. B., Thamdrup, B., Hansen, J. W., Nielsen, L. P., and Hall, P. O.: J. Pathways of organic-carbon oxidation in three continental-margin sediments, Mar. Geol., 113, 27-40, 1993a.

Canfield, D. E., Thamdrup, B., and Hansen, J. W.: The anaerobic degradation of organic-matter in danish coastal sediments - iron reduction, manganese reduction, and sulfate reduction, Geochim. Cosmochim. Ac., 57, 3867-3883, 1993b.

Cathalot, C., Rabouille, C., Pastor, L., Deflandre, B., Viollier, E., Buscail, R., Grémare, A., Treignier, C., and Pruski, A.: Temporal variability of carbon recycling in coastal sediments influenced by rivers: assessing the impact of flood inputs in the Rhône River prodelta, Biogeosciences, 7, 1187-1205, doi:10.5194/bg7-1187-2010, 2010.

Chanton, J. P., Martens, C. S., and Goldhaber, M. B.: Biogeochemical cycling in an organic-rich coastal marine basin. 7. Sulfur mass balance, oxygen uptake and sulfide retention, Geochim. Cosmochim. Ac., 51, 1187-1199. 1987.

Chen, C. T. A. and Borges, A. V.: Reconciling opposing views on carbon cycling in the coastal ocean: continental shelves as sinks and near-shore ecosystems as sources of atmospheric $\mathrm{CO}_{2}$, Deep-Sea Res. Pt. II, 56, 578-590, 2009.
Cline, J. D.: Spectrophotometric determination of hydrogen sulfide in natural waters, Limnol. Oceanog. 14, 454-458, 1969.

Copin-Montegut, C.: Alkalinity and carbon budgets in the Mediterranean Sea, Global Biogeochem. Cy., 7, 915-925, 1993.

Dedieu, K., Rabouille, C., Gilbert, F., Soetaert, K., Metzger, E., Simonucci, C., Jézéquel, D., Prévot, F., Anschutz, P., Hulth, S., Ogier, S., and Mesnage, V.: Coupling of carbon, nitrogen and oxygen cycles in sediments from a Mediterranean lagoon: a seasonal perspective, Mar. Ecol. Progr. Ser., 346, 45-59, 2007.

Deflandre, B., Mucci, A., Gagne, J. P., Guignard, C., and Sundby, B.: Early diagenetic processes in coastal marine sediments disturbed by a catastrophic sedimentation event, Geochim. Cosmochim. Ac., 66, 2547-2558, 2002.

Durrieu De Madron, X. D., Abassi, A., Heussner, S., Monaco, A., Aloisi, J. C., Radakovitch, O., Giresse, P., Buscail, R., and Kerhervé, P.: Particulate matter and organic carbon budgets for the gulf of lions (NW mediterranean), Oceanol. Acta, 23, 717-730, 2000.

Dhakar, S. P. and Burdige, D. J.: A coupled, non-linear, steady state model for early diagenetic processes in pelagic sediments, Am. J. Sci., 296, 244-265, 1996.

Drexler, T. M. and Nittrouer, C. A.: Stratigraphic signatures due to the flood deposition near the Rhône River: Gulf of Lions, northwest Mediterranean Sea, Cont. Shelf Res., 28(15), 2000-2016, 2008.

Epping, E., van der Zee, C., Soetaert, K., and Helder, W.: On the oxidation and burial of organic carbon in sediments of the Iberian Margin and Nazare Canyon (NE Atlantic), Progr. Oceanogr., 52, 399-431, 2002.

Gatti, J., Petrenko, A., Devenon, J.-L., Leredde, Y., and Ulses, C.: The Rhône river dilution zone present in the northeastern shelf of the Gulf of Lion in December 2003, Cont. Shelf Res., 26, 17941805, 2006.

Garcia-Garcia, A., Orange, D., Lorenson, T., Radakovitch, O., Tesi, T., Miserocchi, S., Berné, S., Friend, P. L., Nittrouer, C., and Normand, A.: Shallow gas off the Rhone prodelta, Gulf of Lions, Mar. Geol., 234(1-4), 215-231, 2006.

Haese, R. R., Schramm, J., van der Loeff, M. M. R., and Schulz, H. D.: A comparative study of iron and manganese diagenesis in continental slope and deep sea basin sediments off Uruguay (SW Atlantic), Int. J. Earth Sci., 88, 619-629, 2000.

Hall, P. O. and Aller, R. C.: Rapid, small-volume, flow injection analysis for $\Sigma \mathrm{CO}_{2}$ and $\mathrm{NH}_{4}^{+}$in marine and freshwaters, Limnol. Oceanogr., 37, 1113-1119, 1992.

Hansen, H. P.: Determination of oxygen, Methods of Seawater Analysis, Wiley-VCH Verlag GmbH, 75-89, 2007.

Hansen, H. P. and Koroleff, F.: Determination of nutrients, Methods of Seawater Analysis, Wiley-VCH Verlag GmbH, 159-228, 2007.

Hargrave, B. T. and Phillips, G. A.: Decay times of organic-carbon in sedimented detritus in a macrotidal estuary, Mar. Ecol.-Prog. Ser., 56, 271-279, 1989.

Hargrave, B. T., Holmer, M., and Newcombe, C. P.: Towards a classification of organic enrichment in marine sediments based on biogeochemical indicators, Mar. Pollut. Bull., 56(5), 810-824, 2008.

Hedges, J. I. and Keil, R. G.: Sedimentary organic matter preservation: an assessment and speculative synthesis, Mar. Chem., 49, 81-115, 1995. 
Henrichs, S. M. and Reeburgh, W. S.: Anaerobic mineralization of marine sediment organic matter: rates and the role of anaerobic processes in the oceanic carbon economy, Geomicrobiology, 5, 191-236, 1987.

Helder, W.: Early diagenesis and sediment-water exchange in the Golfe du Lion, European Commission, Brussel, 1989.

Herman, P. M. J., Soetaert, K., Middelburg, J. J., Heip, C., Lohse, L., Epping, E., Helder, W., Antia, A. N., and Peinert, R.: The seafloor as the ultimate sediment trap-using sediment properties to constrain benthic-pelagic exchange processes at the goban spur, Deep-Sea Res. Pt. II, 48, 3245-3264, 2001.

Holligans, P. M. and Reiners, W. A.: Predicting the responses of the coastal zone to global change, Adv. Ecol. Res., 22, 211-255, 1992.

Huerta-Diaz, M. A. and Morse, J. W.: A quantitative method for determination of trace-metal concentrations in sedimentary pyrite, Mar. Chem., 29, 119-144, 1990.

Huerta-Diaz, M. A. and Morse, J. W.: Pyritization of trace metals in anoxic marine sediments, Geochim. Cosmochim. Ac., 56, 26812702, 1992.

Hulth, S., Tengberg, A., Landen, A., and Hall, P. O. J.: Mineralization and burial of organic carbon in sediments of the Southern Weddell Sea (Antarctica), Deep-Sea Res. Pt. I, 44, 955-981, 1997.

Ingall, E. and Jahnke, R.: Evidence for enhanced phosphorus regeneration from marine sediments overlain by oxygen depleted waters, Geochim. Cosmochim. Ac., 58, 2571-2575, 1994.

Jorgensen, B. B.: Sulfur cycle of a coastal marine sediment (Limfjorden, Denmark), Limnol. Oceanogr., 22, 814-832, 1977.

Jorgensen, B. B., Bang, M., and Blackburn, T. H.: Anaerobic mineralization in marine sediments from the Baltic Sea-North transition, Mar. Ecol. Progr. Ser., 59, 39-54, 1990.

Kasih, G. A. A., Chiba, S., Yamagata, Y., Shimizu, Y., and Haraguchi, K.: Numerical model on the material circulation for coastal sediment in Ago Bay, Japan, J. Mar. Syst., 77, 45-60, 2009.

King, G. M., Howes, B. L., and Dacey, J. W. H.: Short-term endproducts of sulfate reduction in a salt marsh formation of acid volatile sulfides, elemental sulfur, and pyrite, Geochim. Cosmochim. Ac., 49, 1561-1566, 1985.

Kostka, J. E. and Luther, G. W.: Partitioning and speciation of solid phase iron in salt-marsh sediments, Geochim. Cosmochim. Ac., 58, 1701-1710, 1994.

Lansard, B., Rabouille, C., Denis, L., and Grenz, C.: In situ oxygen uptake rates by coastal sediments under the influence of the Rhône River (NW Mediterranean Sea), Symposium on Coastal Ecosystem Responses to Changing Nutrient Inputs from Large Temperate and Sub-Tropical Rivers, Fujian, China, 1501-1510, 2005.

Lansard, B., Rabouille, C., Denis, L., and Grenz, C.: Benthic remineralization at the land-ocean interface: a case study of the Rhône River (NW Mediterranean Sea), Estuar. Coast. Shelf Sci., 81, 544-554, 2009.

Littke, R., Baker, D. R., Leythaeuser, D., and Rullkötter, J.: Keys to the depositional history of the Posidonia Shale (Toarcian) in the Hils syncline, Northern Germany. Modern and Ancient Continental Shelf Anoxia, edited by: Tyson, R. V. and Pearson, T. H., Geol. Soc. London, Spec. Publ. 58, 311-334, 1991.

Lückge, A., Ercegovac, M., Strauss, H., and Littke, R.: Early diage- netic alteration of organic matter by sulfate reduction in Quaternary sediments from the Northeastern Arabian Sea, Mar. Geol., 158(1-4), 1-13, 1999.

Mackin, J. E. and Swider, K. T.: Organic matter decomposition pathways and oxygen consumption in coastal marine sediments, J. Mar. Res., 47, 681-716, 1989.

Maerki, M., Muller, B., Dinkel, C., and Wehrli, B.: Mineralization pathways in lake sediments with different oxygen and organic carbon supply, Limnol. Oceanogr., 54, 428-438, 2009.

Marion, C., Dufois, F., Arnaud, M., and Vella, C.: In situ record of sedimentary processes near the Rhône River mouth during winter events (Gulf of Lions, Mediterranean Sea), Cont. Shelf Res., 30(9), 1095-1107, 2010.

Martens, C. S. and Val Klump, J.: Biogeochemical cycling in an organic-rich coastal marine basin 4. An organic carbon budget for sediments dominated by sulfate reduction and methanogenesis, Geochim. Cosmochim. Ac., 48, 1987-2004, 1984.

McKee, B. A., Aller, R. C., Allison, M. A., Bianchi, T. S., and Kineke, G. C.: Transport and transformation of dissolved and particulate materials on continental margins influenced by major rivers: benthic boundary layer and seabed processes, Cont. Shelf Res., 24, 899-926, 2004.

Miralles, J., Radakovitch, O., and Aloisi, J. C.: Pb-210 sedimentation rates from the northwestern mediterranean margin, Mar Geol., 216, 155-167, 2005.

Monaco, A., de Madron, X. D., Radakovitch, O., Heussner, S., and Carbonne, J.: Origin and variability of downward biogeochemical fluxes on the Rhone continental margin (NW Mediterranean), Deep-Sea Res. Pt. I, 46, 1483-1511, 1999.

Morse, J. W. and Eldridge, P. M.: A non-steady state diagenetic model for changes in sediment biogeochemistry in response to seasonally hypoxic/anoxic conditions in the "dead zone" of the Louisiana shelf, Mar. Chem., 106, 239-255, 2007.

Mucci, A. and Morse, J. W.: The solubility of calcite in seawater solutions of various magnesium concentration, it $=0.697 \mathrm{~m}$ at $25^{\circ} \mathrm{C}$ and one atmosphere total pressure, Geochim. Cosmochim. Ac., 48, 815-822, 1984.

Pastor, L., Deflandre, B., Viollier, E., Cathalot, C., Metzger, E.,Rabouille, C., Escoubeyrou, K., Lloret, E., Pruski, A., Vétion, G., Desmalades, M., Buscail, R., and Grémare, A.: Influence of the organic matter composition on benthic oxygen demand in the Rhône River prodelta (NW Mediterranean Sea), Cont. Shelf Res., 31, 1008-1019, 2011.

Pedersen, T. F. and Price, N. B.: The geochemistry of manganese carbonate in panama basin sediments, Geochim. Cosmochim. Ac., 46, 59-68, 1982.

Pont, D., Simonnet, J. P., and Walter, A. V.: Medium-term changes in suspended sediment delivery to the ocean: Consequences of catchment heterogeneity and river management (Rhône River, France), Estuar. Coast. Shelf Sci., 54, 1-18, 2002.

Pratihary, A. K., Naqvi, S. W. A., Naik, H., Thorat, B. R., Narvenkar, G., Manjunatha, B. R., and Rao, V. P.: Benthic fluxes in a tropical Estuary and their role in the ecosystem, Estuar. Coast. Shelf Sci., 85, 387-398, 2009.

Quintana, C. O., Tang, M., and Kristensen, E.: Simultaneous study of particle reworking, irrigation transport and reaction rates in sediment bioturbated by the polychaetes heteromastus and marenzelleria, J. Exp. Mar. Biol. Ecol., 352, 392-406, 2007.

Rabouille, C. and Gaillard, J. F.: Toward the EDGE: Early diage- 
netic global explanation: A model depicting the early diagenesis of organic matter, $\mathrm{O}_{2}, \mathrm{NO}_{3}, \mathrm{Mn}$, and $\mathrm{PO}_{4}$, Geochim. Cosmochim. Ac., 55, 2511-2525, 1991.

Radakovitch, O., Charmasson, S., Arnaud, M., and Bouisset, P.: Pb210 and caesium accumulation in the Rhone delta sediments, Estuar. Coast. Shelf Sci., 48, 77-92, 1999.

Raiswell, R., Canfield, D. E., and Berner, R. A.: A comparison of iron extraction methods for the determination of degree of pyritisation and the recognition of iron-limited pyrite formation, Chem. Geol., 111, 101-110, 1994.

Rasmussen, H. and Jorgensen, B. B.: Microelectrode studies of seasonal oxygen uptake in a coastal sediment: role of molecular diffusion, Mar. Ecol. Prog.-Ser., 81, 289-303, 1992.

Revsbech, N. P.: An oxygen microsensor with a guard cathode, Limnol. Oceanogr., 34, 474-478, 1989.

Rhoads, D. C. and Cande, S.: Sediment profile camera for in situ study of organism-sediment relations, Limnol. Oceanogr., 16, 110-114, 1971.

Rizzo, W. M. and Christian, R. R.: Significance of subtidal sediments to heterotrophically mediated oxygen and nutrient dynamics in a temperate estuary, Estuaries, 19, 475-487, 1996.

Rysgaard, S., Thamdrup, B., Risgaard-Petersen, N., Fossing, H., Berg, P., Christensen, P. B., and Dalsgaard, T.: Seasonal carbon and nutrient mineralization in a high-arctic coastal marine sediment, young sound, Northeast Greenland, Mar. Ecol.-Prog. Ser., 175, 261-276, 1998.

Sempéré, R., Charriere, B., Van Wambeke, F., and Cauwet, G.: Carbon inputs of the Rhône River to the Mediterranean Sea: biogeochemical implications, Global Biogeochem. Cy., 14, 669-681, 2000 .

Soetaert, K. and Herman, P. M. J.: "A practical guide to ecological modelling - using R as a simulation platform", Springer Science + Business Media, B.V., 372 pp., 2009.

Soetaert, K., Herman, P. M. J., and Middelburg, J. J.: A model of early diagenetic processes from the shelf to abyssal depths, Geochim. Cosmochim. Ac., 60, 1019-1040, 1996a.

Soetaert, K., Herman, P. M. J., and Middelburg, J. J.: Dynamic response of deep-sea sediments to seasonal variations: a model, Limnol. Oceanogr., 41, 1651-1668, 1996b.

Soetaert, K., Herman, P. M. J., Middelburg, J. J., and Heip, C.: Assessing organic matter mineralization rate, degradability and mixing rate in an ocean margin sediment (North-East Atlantic) by diagenetic modelling, J. Mar. Res., 56, 519-534, 1998.

Soetaert, K., Petzoldt, T., and Meysman, F.: marelac: Tools for Aquatic Sciences. R package version 2.1, available at: http: //cran.r-project.org/web/packages/marelac, 2010.
Tabatabai, M. A.: A rapid method for determination of sulfate in water samples, Environ. Lett., 7(3), 237-243, 1974.

Tesi, T., Miserocchi, S., Goni, M. A., and Langone, L.: Source, transport and fate of terrestrial organic carbon on the Western Mediterranean Sea, Gulf of Lions, France, Mar. Chem., 105, 101-117, 2007.

Thamdrup, B. and Dalsgaard, T.: The fate of ammonium in anoxic manganese oxide-rich marine sediment, Geochim. Cosmochim. Ac., 64(24), 4157-4164, 2000.

Thamdrup, B., Fossing, H., and Jorgensen, B. B.: Manganese, iron and sulfur cycling in a coastal marine sediment, Aarhus Bay, Denmark, Geochim. Cosmochim. Ac., 58, 5115-5129, 1994.

Thomsen, U., Thamdrup, B., Stahl, D. A., and Canfield, D. E.: Pathways of organic carbon oxidation in a deep lacustrine sediment, Lake Michigan, Limnol. Oceanogr., 49, 2046-2057, 2004.

Tromp, T. K., Van Cappellen, P., and Key, R. M.: A global model for the early diagenesis of organic carbon and organic phosphorus in marine sediments, Geochim. Cosmochim. Acta, 59(7), 12591284, 1995.

Van Cappellen, P. and Wang, Y.: Cycling of iron and manganese in surface sediments: a general theory for the coupled transport and reaction of carbon, oxygen, nitrogen, sulfur, iron, and manganese, Am. J. Sci., 296, 197-243, 1996.

Wakeham, S. G., Lee, C., Hedges, J. I., Hernes, P. J., and Peterson, M. L.: Molecular indicators of diagenetic status in marine organic matter, Geochim. Cosmochim. Ac., 61(24), 5363-5369, 1997.

Wang, Y. and Van Capellen, P.: A multicomponent reactive transport model of early diagenesis: application to redox cycling in coastal sediments, Geochim. Cosmochim. Ac., 60, 2993-3014, 1996.

Westrich, J. T. and Berner, R. A.: The role of sedimentary organic matter in bacterial sulfate reduction - the g model tested, Limnol. Oceanogr., 29, 236-249, 1984.

Wijsman, J. W. M., Herman, P. M. J., Middelburg, J. J., and Soetaert, K.: A model for early diagenetic processes in sediments of the continental shelf of the Black Sea, Estuar. Coast. Shelf Sci., 54, 403-421, 2002.

Wollast, R.: Evaluation and comparison of the global carbon cycle in the coastal zone and in the open ocean, in: The Sea, the Global Coastal Ocean, Processes and Methods, edited by: Brink, K. H. and Robinson, A. R., Wiley and Sons, New York, 213-252, 1998.

Zuo, Z., Eisma, D., and Berger, G. W.: Determination of sediment accumulation and mixing rates in the Gulf of Lions, Mediterranean Sea, Oceanol. Acta, 14, 253-262, 1991.

Zuo, Z., Eisma, D., Gieles, R., and Beks, J.: Accumulation rates and sediment deposition in the North-Western Mediterranean, DeepSea Res. Pt. II, 44, 597-609, 1997. 